\title{
Against the Grain: Spanish Trade Policy in the Interwar Years
}

\author{
Concepción Betrán and Michael Huberman
}

We study the effects of domestic conflict and external shocks on Spanish trade policy in the interwar period. Our account mobilizes a new granular dataset on exports and imports, and good-country level information on tariffs, trade agreements, and quotas. Into the Depression, the mainstay of policy was the tariff. The establishment of the Second Republic in 1931 was a turning point in policymaking. The new regime initiated bilateral trade negotiations. The Republic's dilemma was to find countries willing to exchange market access. In a daunting international environment, the Spanish case offers a poignant reminder of the perils of going against the grain.

\section{$\mathrm{T}$} he economic crisis of the interwar decades triggered global shock waves, but some countries were better positioned to insulate themselves than others. As a small, predominantly agricultural economy on the periphery of Europe, Spain is thought to have been one such country. Long-established tariffs shielded domestic industry and the country had suspended gold convertibility at an early date, 1883 (Temin 1993). ${ }^{1}$ Under these circumstances, the pressure to develop a new set of policies to confront the headwinds of the interwar shocks was weak. ${ }^{2}$ By

The Journal of Economic History. (C) The Author(s), 2021. Published by Cambridge University Press on behalf of the Economic History Association. This is an Open Access article, distributed under the terms of the Creative Commons Attribution licence (http://creativecommons.org/ licenses/by/4.0/), which permits unrestricted re-use, distribution, and reproduction in any medium, provided the original work is properly cited. doi: 10.1017/S0022050721000474

Concepción Betrán is Professor, Department of Economic Analysis, Universitat de València, Campus dels Tarongers, Av. dels Tarongers, s/n 46022 Valencia, Spain. E-mail: concepcion. betran@uv.es. Michael Huberman is Professor, Département d'histoire, Université de Montréal, Pavillon Lionel-Groulx, C. P. 6128, succursale Centre-ville Montréal, Québec, H3C 3J7, Canada. E-mail: michael.huberman@umontreal.ca (corresponding author).

We thank the referees and Dan Bogart for helpful comments and suggestions. We benefitted from discussion at the 2018 World Economic History Conference (Boston), and the 2019 European Historical Economics Society Conference (Paris); and seminars at the Universidad de Zaragoza (November 2018), Paris School of Economics (May 2019), and the Vienna University of Economics and Business (October 2019). We will value the contribution of Pedro Lains at the 2019 Iberometrics Conference (Alcalá, Spain). Michael Huberman acknowledges the financial support of the Chaire McConnell en études américaines, Université de Montréal. Concepción Betrán has received financial support from the Spanish Ministry of Economy and Competitiveness, MINECO/FEDER ECO2015-66782-P and PID2019-108645 GB-100, and from the Generalitat Valenciana AICO/2018/130. Ana Mar Bueno and Cefe Ferrer provided excellent research assistance. This article's replication kit is available at the Journal's OpenICPSR Repository, project 136461 (Betrán and Huberman 2021).

${ }^{1}$ For similar claims, see Carreras and Tafunell (2004, p. 254), Serrano Sanz (1987, p. 148), and Palafox (2011, p. 95).

${ }^{2}$ Spanish trade policy in the period and, more generally, the international sector have received considerably less attention than domestic policy such as agrarian reform. Richmond (1987), Serrano Sanz (1987), and Viñas et al. (1979) are exceptions. 
extension, the advent of the Second Republic in 1931, despite the support of different interest groups and with a different domestic program, did not mark a major break in policy with the preceding autocratic regime of Miguel Primo de Rivera (Payne 1993, p. 151). In any event, small countries had few policy options in the context of the global collapse of trade in the 1930s. By the eve of the Civil War, Spain had decoupled itself from the international economy. Prior to and immediately after WWI, the value of trade as a share of GDP stood at approximately 24 percent; by 1936, the figure was 10 percent (Tena 2005 p. 578).

This paper reconsiders these views through the prism of trade policy. We counter the claim that Spain was effectively sheltered from the economic shocks of the interwar decades. Instead, Spanish decision makers sought to adapt trade policy to balance the tension between international pressures and domestic concerns. The international environment was exceptionally unfavorable. Sudden and abrupt exchange rate movements threatened flows of foreign capital, and the collapse in world agricultural prices and discriminatory practices of major trading partners had aggravated the Spanish trade deficit. On the domestic front, the transition to democracy in 1931 empowered economic, social, and political interest groups - landless laborers, trade unions, the liberal middle classes, women, and others - that the preceding regime had sidelined. ${ }^{3}$ Domestic politics and international economic relations were interdependent, or in the words of Robert Putnam (1988, p. 427), "somehow often entangled." We claim that external shocks imposed limits on domestic policy, whereas domestic interests shaped the direction of trade policy. ${ }^{4}$ In this fashion, Spain, despite a low and contracting degree of openness, was not unexposed to the interwar crisis. ${ }^{5}$ To be sure, the tension between domestic politics and international forces was not particular to Spain. But the establishment of a democratic regime was an exceptional occurrence even as the specter of authoritarianism was gaining force elsewhere in Europe. In this regard, we provide a fresh perspective on interwar international economic history.

Our study of trade policy exploits a new granular dataset on exports and imports between 1922 and 1935. We align our disaggregated trade data

\footnotetext{
${ }^{3}$ In 1931, the eligible age of male voters was reduced from 25 to 23 years of age. The Constitution of October 1931 granted women the right to vote, which was first exercised in 1933.

${ }^{4}$ Previously, Manuel Azaña (1986, pp. 26-28), Prime Minister (1931-1933), and President (1936-1939) of the Second Republic, made the same observation.

${ }^{5}$ The degree of openness conventionally measured as exports and imports as a share of GDP is an imprecise indicator since it conflates outcomes and processes. Measured in this fashion, a low degree of openness may represent a preference for home goods, but it could as well expose the response of trade policy to open-economy forces.
} 
with good-country information on tariffs, most-favored-nation (MFN) agreements, and quantitative controls, and other discriminatory practices. The level of detail affords an unobstructed window on the manner in which international trade of a small country like Spain adapted to domestic challenges and external shocks. To do so, we follow recent advances in the economic history of international trade and decompose the value of exports and imports into intensive (the value of trade in continuous goods) and extensive margins (the number of products and countries with whom Spain traded). ${ }^{6}$ At the most general level, the intensive margin refers to changes in trade that occur in preexisting or continuous relationships, such as the effect of Imperial Preference on Spanish citrus exports to the United Kingdom in the 1930s. The extensive margin refers to changes in the entry or exit of products and countries, such as Spain's discontinuing imports of iron and steel goods from France in the same period. The relative importance of the margins varies along temporal and spatial dimensions. The size of the intensive margin tends to be significant in the short run because continuous relationships dominate in brief intervals (Bernard et al. 2009). Fluctuations in demand for continuous goods show up along the intensive margin. ${ }^{7}$ The extensive margin captures changes in the expansion and contraction of the geographic scope of markets. ${ }^{8}$ Pinned down by the gravity relationship, the number of products traded declines with distance (Schott 2009). Trade policy affects both margins. A general tariff reduction increases import demand of continuous goods and possibly introduces new goods in the home market as well. ${ }^{9}$

Thomas Chaney's (2008) model of the relationship between trade costs and the margins of trade frames our account of the effectiveness of trade policy. In Chaney's setup, variable trade costs affect both margins of trade, but fixed costs affect only the extensive side. Consider Spain's signing of a conditional MFN accord with Italy in 1932. The fall in trade barriers promoted imports and exports of continuous goods along the intensive margin. The removal of barriers also reduced the fixed costs of entry into the Spanish and Italian markets, the number of goods traded

\footnotetext{
${ }^{6}$ These studies include Betrán and Huberman (2016), de Bromhead et al. (2019a, 2019b), Huberman, Meissner, and Oosterlinck (2017), and Meissner and Tang (2018). We provide more precise definitions of the margins of trade in the third section of the paper.

${ }^{7}$ For instance, Levchenko, Lewis, and Tesar (2010) attribute the relatively large intensive margin during the brief trade collapse of 2008-2009 to a sharp decline in demand.

${ }^{8}$ Along these lines, Dutt, Mihov, and Van Zandt (2013) conclude that increased membership in the WTO had a sizeable effect on the extensive margin.

${ }^{9}$ Debaere and Mostashari (2010) study the effect of U.S. tariff changes after 1945 on the extensive margin of imports. They report that lower U.S. tariffs increased the number of goods imported, but the overall contribution to trade was small.
} 
between the two countries, the extensive margin, increasing as a result. The MFN accords actually stipulated these new items. We contend that because of the obstacles impeding international trade in the interwar period, trade agreements enabling market entry for specific goods became an ever more important instrument of policy. These types of MFN accords underline our claim that trade policy mattered.

The decomposition of trade into intensive and extensive margins raises issues with a classic interpretation of the great trade collapse of the interwar period. In this account, the decline in trade after 1929, a consequence of the sharp contraction in income and demand, was mainly along the intensive margin, trade policy having a secondary role (Irwin 2012; Madsen 2001). ${ }^{10}$ The inference is that if trade were to have rebounded, it would have looked a lot like the type of trade before the crisis. But these early studies are narrow in scope because they rely on coarse trade statistics. Our good-country level information on trade and policy improves on these studies. We find that in the case of Spain, the extensive margin was by no means insignificant. The conjecture is that if trade were to have recovered, it would have been different than trade before 1929.

We divide Spanish trade policy before the Civil War into three intervals: the 1920s, the Depression years, 1929-1931, and the first and second biennium of the Second Republic, 1931-1936. Each period exhibited a distinct relationship between domestic forces and international pressures. Serving long-established interest groups, policy after WWI was a mixed strategy. The tariff was the primary instrument of policy, although in 1927 Spain negotiated unconditional most-favored national agreements in an attempt to secure foreign exposure for traditional export sectors. With the onset of the Depression, Spain responded customarily, adopting stiff tariff measures to protect the peseta and retaliate against the protectionism of major trading partners.

The restoration of Spanish democracy in 1931 marked a change in policy direction. The new government faced the daunting problem of reconciling the aspirations of constituents with the external constraints imposed by the volatile international order. Spain's trading partners pursued diverse and shifting responses to the Depression. The rules of engagement were fluid, and market access at home and abroad was no longer guaranteed. In contrast to France, Portugal, and the United

\footnotetext{
${ }^{10}$ Kevin O'Rourke (cited in Smith 2019) is sanguine on the effect of interwar policy on the trade contraction: "Everybody [economists] agrees that protectionism is a bad thing...But when you try to quantify it, you often end up finding that it didn't matter very much." https://www. aeaweb.org/research/british-interwar-protectionism-imperial-imports
} 
Kingdom, Spain lacked the advantages of an empire or a natural trading bloc (Jacks and Novy 2020), with the exception of Spanish Morocco and Equatorial Guinea. Turning the page on retaliatory tariffs, the Second Republic sought, in the phrase of one key supporter, "collaboration" (Vives 1931, p. 41) with commercial partners in the reconstruction of a stable international trading order. To this end, the new regime negotiated reciprocal agreements, often embedded in conditional MFN accords, that conceded domestic market access in exchange for improved exposure abroad for Spanish goods. ${ }^{11}$ MFNs locked in trading partners and guaranteed market entry, lifting the shadow of uncertainty caused by the period's imposing barriers to international trade. Trade agreements of this type alter the geographic scope of trade, a transformation that showed up in the extensive margins of imports and exports.

The paper is organized into four remaining sections. We begin with an overview of Spanish trade policy in the interwar period. We find variation in policies across goods, countries, and political regimes. We give special attention to the changing nature and content of MFN agreements, from unconditional to conditional, and the shift from multi to bilateral negotiations. In the third section, we introduce the granular trade data on imports and exports compiled to evaluate our claims. We decompose trade into intensive and extensive margins. The fourth section reports the regression results of the effects of tariffs, MFNs, and quotas on the margins of trade. We find that bilateral MFN agreements increased both the value and number of imports. As for exports, the new MFN agreements had a modest impact on trade. In the concluding section, we summarize our findings for the literature on the Great Depression and Spanish economic history.

\section{SPANISH TRADE POLICY IN THE INTERWAR PERIOD}

\section{Trade Policy in the 1920 s}

Spain did not participate in WWI and, as a result, policy in the 1920s was very much along the lines of that pursued before the conflict. In the prosperous 1920s (Prados de la Escosura and Rosés 2009; Prados de la Escosura and Sánchez-Alonso 2019), urbanization and wage

\footnotetext{
${ }^{11}$ The Second Republic's embrace of "progressive bilateralism" (Irwin 1993, p. 112) coincided with a comparable shift in U.S. trade policy. In 1934 Cordell Hull's Reciprocal Trade Act authorized bilateral agreements, although Irwin $(1993,2017)$ finds that the provision had limited success before 1940 .
} 


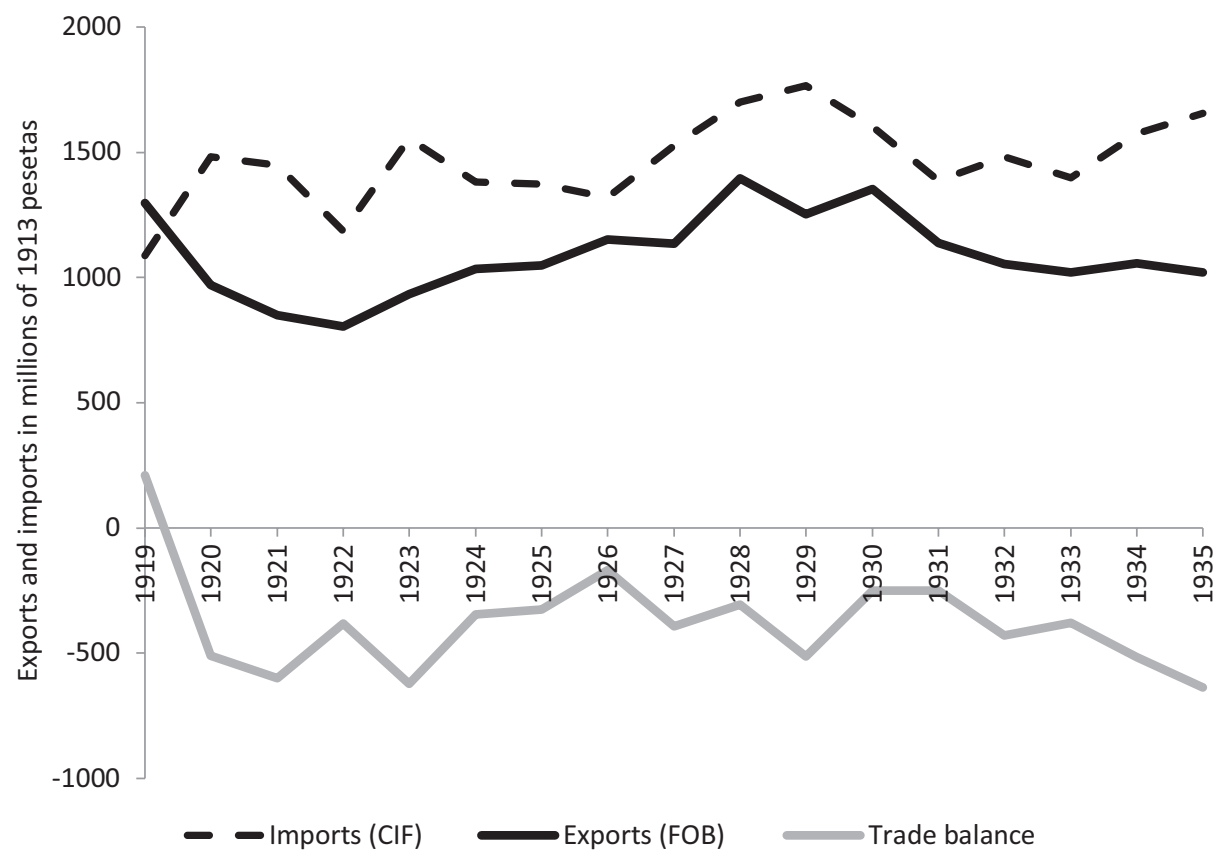

FIGURE 1

IMPORTS, EXPORTS, AND THE TRADE BALANCE, 1919-1935

Notes: All values in millions of 1913 pesetas. Trade is special trade. Reexports are excluded. Source: Tena (2005).

growth, together with the expansion of the chemical and metal industries, spurred demand for imports of intermediate and final goods (Figure 1). ${ }^{12}$ The war briefly triggered a surge in exports. However, unusual for a country of its size and income, Spain sold few manufacturing goods abroad. Agricultural products dominated, amounting to 60-70 percent of exports in the 1920s. Shipments of fruits and olives offset the decline in wine exports that had peaked before the war (Pinilla and Ayuda 2002, 2010; Ramón-Muñoz 2000). ${ }^{13}$ Oranges mainly from the Valencia region comprised about 50 percent of world exports by the close of the $1920 \mathrm{~s}$ (Garrido 2010, p. 240). The United Kingdom alone purchased 40 percent of Spain's exports (Palafox 1979, 1983, p. 343; Simpson 1996, p. 217), affording orange producers nearly 80 percent of the British market in

\footnotetext{
12 The annual growth rate of real GDP per head in Spain from 1921 to 1929 was 2.89 percent. Calculated from Prados de la Escosura (2017).

${ }^{13}$ Between 1914-1920, fruits, grapes, and olives accounted for 11.3 percent of exports; by 1929-1935, the figure was 31.1 percent (Ayuda and Pinilla 2020, p. 4). Approximately 85 percent of the orange crop was exported (Garrido 2010, p. 228).
} 
1930 (Garrido 2010, pp. 226, 239). The country was the world's largest exporter of olive oil in the first third of the century (Simpson 1996, p. 215). Overall, the lack of diversity in export products and markets, a feature we explore later, had ramifications for the type, direction, and eventual success of trade policy.

Established interest groups and politically connected elites retained a strong hand in trade policy. These groups represented grain, rice, sugar, and wine producers, as well as textile manufacturers, coal-mine owners, and iron and steel magnates. Repeated demands for industrial promotion in the context of post-war dislocation and inflationary pressures forced the state to adopt tried-and-tested responses in its attempts to manage the intractable trade imbalance. Before 1914 the floating exchange rate had stabilized at the longstanding official parity set in 1868 , but after the war, the peseta began to lose value against major currencies, with the exception of the French franc. The government introduced short-term exchange controls in 1919 to staunch capital outflows (Martín-Aceña, Martínez, and Nogués 2011). However, the tariff remained the bedrock of policy. A new classification was introduced in 1922 to accommodate the increase in the number of items traded. Manufacturing rates increased, the average duty of nearly 35 percent ( 20 percent weighted) exceeded pre-war levels (Tena 2010). But keeping to the earlier structure, Spanish authorities applied a two-tier or column tariff. ${ }^{14}$ The first column was intended for countries that did not have a trade treaty with Spain; the second was applied to favored countries. Occasionally, a special tariff (which set duties at the lowest level) was applied to specific products in MFN treaties. Against all countries, the tariff on iron and steel, heavy industry, textiles, horses, olive oil, among other products, was increased in 1926-1927. These policies had modest success - the trade balance in Figure 1 improving slightly in the mid-1920s.

Trade negotiations were by and large adversarial. Those with France were typical. The country was an important market for Spanish wines before the war, and authorities sought to restore foreign sales. ${ }^{15}$ But the French position hardened as the peseta fell against the franc in the early 1920s. France subsequently rejected the second-column tariff on its manufactured goods, compelling Spain in 1922 to make approximately 90 concessions, amounting to duties $20-30$ percent lower than

\footnotetext{
${ }^{14}$ On the tariff structure, see Online Appendix A for details.

${ }^{15}$ In 1890 wine exports comprised 53 percent of Spanish exports; by 1929-1935, the figure was 12 percent. After the war, Spain had lost its traditional markets in the New World because of protectionist policies in Argentina, Uruguay, and the United States (Pinilla and Ayuda 2002; Fernández and Pinilla 2018).
} 
the second-column rate. Spain did receive greater access for wine and agricultural exports, but by 1930 France had also revoked many of these exemptions. Joseph Jones (1934, p. 47), a keen American observer of intra-European trade, commented that the agreement was a lost opportunity since it was designed to meet the needs of established sectors of the economy that had aligned themselves with the dictatorship, whereas new dynamic growth poles were "sacrificed."

The government of Primo de Rivera negotiated conditional MFNs in the mid to late 1920s. Table 1 reports the percentage of products covered in these treaties. Beginning in 1927, inspired by discussions at the previous year's World Economic Conference that aimed to restore the multinational trading system, Spain signed unconditional MFN agreements covering all traded products with Austria, Belgium, Hungary, Italy, several Scandinavian countries, the United Kingdom, the British Dominions, and others. On the eve of the Depression, 42 countries participated in the renewed and reformed multilateral system (Irwin 1993, p. 105). ${ }^{16}$ Many of these agreements remained in place until 1931.

\section{The Trade Channel and the Great Depression, 1929-1931}

The Spanish economy was exposed to the shocks of the Great Depression despite its flexible exchange-rate policy and narrow degree of openness. ${ }^{17}$ The reconstructed MFN network was short-lived as many countries like France reneged on treaty agreements. Seeking to stem capital flight, authorities intervened in 1928 to guarantee the value of the peseta, although without much success (Martín-Aceña, Martínez, and Nogués 2011). ${ }^{18}$ As ever, the government's response to the Depression relied heavily on stricter tariff measures. The Wais Tariff approved in July 1930 was among the last measures taken by the old regime. ${ }^{19}$ Spanish authorities defended the tariff as retaliation against discriminatory French trade practices and the United States' adoption of Smoot-Hawley (Jones 1934, p. 53). The depreciating peseta, whose value had been held up as a

\footnotetext{
${ }^{16}$ On Spain's participation at the 1927 conference, see Jones (1934), League of Nations (1942), and Serrano Sanz (1987). Spain's engagement with unconditional MFNs commenced with the Royal Decree of July 1927. Many of the agreements were signed before December 1928.

${ }_{17}$ The contraction in GDP per capita was larger than the United Kingdom's but smaller than that of France and Germany (Maddison Project 2018).

${ }^{18}$ Between 1927 and 1931, the nominal exchange rate fell by 35 percent against the British pound and by more than 50 percent with respect to the French franc and the U.S. dollar. JorgeSotelo (2019) evaluates the effectiveness of Spanish monetary and exchange rate policy during the Depression.

${ }^{19}$ Additional tariffs on aluminum and related goods in 1928 and on automobiles, films, and other items in 1930 were directed against the United States. See Online Appendix D for details.
} 


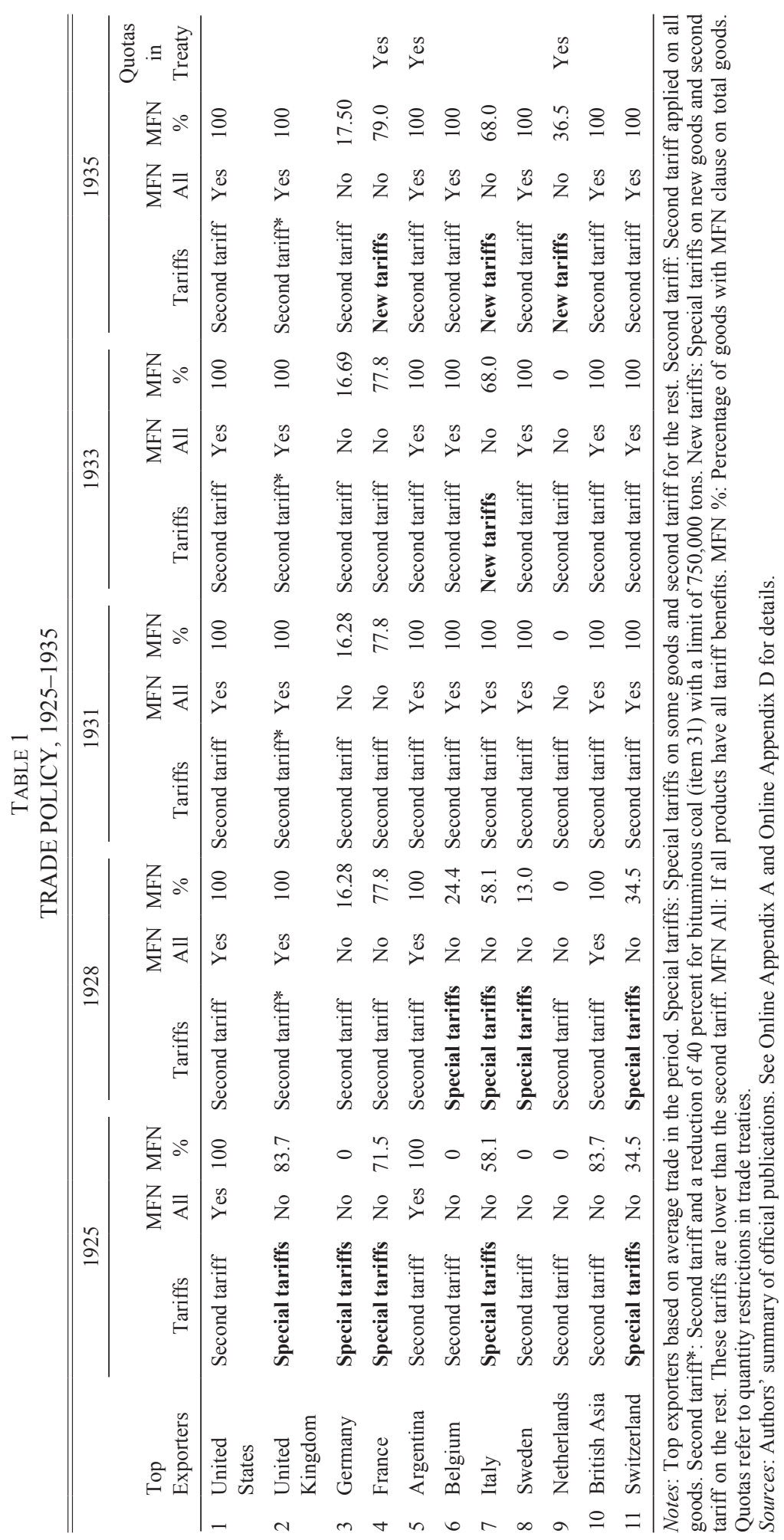


symbol of strength and purpose, damaged the reputation of the outgoing government.

The turbulence of the interwar period cast an unbroken shadow on the Second Republic. Proclaimed in April 1931, the new government inherited an exposed banking sector and enacted capital controls a month later (Jorge-Sotelo 2019). In concert, the value of exports declined abruptly. Flexible exchange rates had apparently afforded only partial cover from international shocks (Betrán, Martín-Aceña, and Pons 2012). ${ }^{20}$ In this fashion, international trade operated as a channel transmitting the global depression to Spain (Betrán 2020). As early as May 1931, supporters of the fledgling regime began advocating the reappraisal of the dictatorship's "dismal tariff policy" (Vives 1931, p. 28). Nonetheless, in the period until September 1931, when the United Kingdom suspended gold convertibility and the peseta stabilized, the Second Republic was challenged to develop an alternate trade policy.

\section{Trade Policy of the Second Republic, 1931-1936}

The Azaña government, a coalition of liberal and socialist reformers, represented a diverse and often conflicting set of constituents, comprising in the urban sector workers, manufacturers, and industrialists, and in the countryside landless agricultural laborers, tenants, and small farmers. ${ }^{21}$ Regional interests, like that of Valencia citrus growers who remained loyal to the republic into the Civil War period, multiplied the demands on the Azaña coalition. The influence of traditional groups such as grain growers waned.22 Emboldened by narrowing wage inequality, the clamor for major reforms intensified (Comín 2002; Prados de la Escosura and Sánchez-Alonso 2019). In the span of the first biennium, 1931-1933, the government adopted a wide-ranging political and social package, including the separation of Church and state, agrarian reform,

\footnotetext{
${ }^{20}$ The collapse in foreign markets was exacerbated by the uncertainty exporters faced because of currency controls (Richmond 1987).

${ }^{21}$ Elected in June 1931, the governing coalition of Socialists, Radicals, and left Republicans held intact until late 1933 (Casanova 2010, p. 37; Payne 1993; Preston 1994). Malefakis (1970, p. 319) observes that socialist members in the government accepted the budget constraint and demonstrated moderation in their demands. Coalition partners were separated more "by their political styles [than] by their policies" (Malefakis 1970, p. 164).

${ }^{22}$ In August 1931, Castilian grain growers objected that the price fixed for wheat was too low, but the new government responded that price-fixing was actually established under the previous regime in 1925-1926, and, anyway, the middle class was best served by low prices. The extended debate that ensued was an occasion for the new government to separate the concerns of their constituents from those of supporters of the dictatorship. Spain, Diario de Sesiones del Congreso de Diputados: sessions 4, 5, 6, and 7 (August 1931), no. 14, pp. 270-74; no. 15, pp. 291-96; no. 16, pp. 308-14; no. 17, pp. 325-35.
} 
an ambitious public education project, an overhaul of the armed forces, and the prospect of autonomy for the regions (Malefakis 1970; Preston 1994). But the new social policies came up against a balance of payments constraint. The diaries and other writings of Azaña (1976, vols. 1 and 2 ; 1986, pp. 26-28) convey the international constraints on domestic policy. The higher unit costs of new labor laws had made competing imports more attractive. In the countryside, economic prospects dimmed because of depressed agricultural prices, the partial land reform, and the pressing unemployment of return migrants from urban centers (Simpson and Carmona 2020). Capital inflows had dried up, and after 1931 the trade deficit swelled (Figure 1).

In the absence of a multilateral network, the challenge for a small economy like Spain was formidable because responses to the Depression varied across major trading partners and trading blocs (Eichengreen and Irwin 2010). ${ }^{23}$ Several countries, most prominently the United Kingdom and the United States, abandoned gold and devalued their currency. Belgium, France, and Switzerland maintained convertibility, raising tariffs and adopting discriminatory policies instead, and still others, such as Germany, relied on exchange controls. These discriminatory practices aside, trading blocs diverted international commerce. France substituted Algerian wine for Spanish varieties and Portugal turned its attention toward Angola and Mozambique (Leitão et al. 2019). Valencia citrus growers lost their privileged access to the British market after the introduction of the Imperial Preference system in 1932, which favored imports from Palestine and South Africa. ${ }^{24}$ Because of the heterogeneity in responses, the task for Spanish authorities was complex and costly since they were obligated to undertake negotiations on a country-by-country basis.

By the early 1930s, the new government began to hold back on tariff adjustments, although the degree of protectionism was maintained, as was the two-column tariff structure. ${ }^{25}$ From an international lens, Spain

\footnotetext{
${ }^{23}$ At the outset of his tenure, Azaña leaned toward orthodox responses to the Depression in order to preserve international support for the new democracy. But after Britain left gold, he came to favor an interventionist policy. The financial press gave extensive coverage to the change in policy. See, for instance, El Financiero (24 June 1932) and Revista Nacional de Economía (February 1933, no. 107).

${ }^{24}$ On Spanish agricultural exports to the United Kingdom, see Jackson (1965, pp. 87-89), Richmond (1987, pp. 355-56), and Viñas et al. (1979, pp. 85-86).

${ }^{25}$ The tariff actually increased because of the period's deflation. Before 1945 specific duties were common in Spain. In real terms, the ad valorem tariff rate increased automatically as the price of goods in the 1930s fell (Crucini 1994; Crucini and Kahn 1996). But even under these circumstances, countries could opt to increase duties as a retaliatory measure, for instance, against countries on gold that were prone to raise tariffs and adopt discriminatory measures (Eichengreen and Irwin 2010).
} 
would appear to have participated in the period's "tariff truce" (League of Nations 1942, p. 141; Saz 1985). The regime opted for a more conciliatory policy of securing markets for Spanish exports. The centerpiece was the negotiation of bilateral arrangements embedded in MFNs that sought to exchange domestic market access for enlarged exposure of Spanish goods in foreign markets. The objective was to preserve continuous trading relationships and establish new ones, assuring to some extent demand for Spanish exports. The expectation was that bilateral arrangements would ultimately be extended to other commercial partners and become the scaffolding of a new multilateral network. ${ }^{26}$ In parliamentary debate, the Lliga Catalana deputy, Carlos Badía Malagrida, referred to the policy as "comprar a quien nos compra," or "buy from those who buy from us." 27

Both ideas and interests lay behind the policy shift. As ever, these forces are difficult to disentangle (Mukand and Rodrik 2018). The restoration of world trade was central to discussions at the 1933 international conference in London and the preparatory 1932 meetings in Geneva, although no decisive action was taken at their conclusion (League of Nations 1942). These ideas were also debated in the Spanish Parliament. ${ }^{28}$ Proposals cleaved along ideological lines: left and liberal representatives contended that it was Spain's interest to adopt bilateral arrangements to secure markets, while those on the right of the political spectrum wanted to protect domestic industries using stringent tariffs and discriminatory quotas. The various positions mapped onto regional economic interests..$^{29}$ On the one hand, deputies from Valencia sought markets for citrus producers, and

\footnotetext{
${ }^{26}$ The official decrees referred explicitly to the goal of exchanging imports for exports (Spain, Gaceta Oficial de Madrid, no. 358, 24 December 1931, pp. 1899-1900; no. 361, 27 December 1933, pp. 2170-71). The policy was summarized in El Financiero, 12 January 1934. Lampe (2009) describes the presence of a comparable policy initiative embedded in the "reciprocal bilateral" treaties of the Cobden-Chevalier network.

${ }^{27}$ Spain, Diario de Sesiones, 3 January 1934, no. 15, pp. 280-85 and 5 January 1934, no. 17 pp. 330-49. See the follow-up debate, 6 April 1934, no. 64, pp. 2088-2100. The Lliga was a regional Central Republican party that represented the interests of the Catalan business community (Irwin 1991, p. 174). Because of previous experience as a trade delegate, Badía was chosen to lead treaty negotiations with France in 1934. He also participated in the parliamentary debate on the adoption of quotas (Spain, Diario de Sesiones, 30 January 1935, no. 150, pp. 5936-55).

${ }^{28}$ The debates took place between 1931 and 1935. Spain, Diario de Sesiones, 23 October 1931, no. 62 , pp. 1932-35; 3 December 1931, no. 85, pp. 2197-2801; 20 July 1932, no. 203, pp. 7219 20; 21 February 1933 , no. 294, p. 11123; 8 August 1933, no. 384, pp. 14694-96; 5 January 1934, no. 17 , pp. 330-49; 31 January 1934, no. 15 , pp. 280-85; 6 April 1934, no. 64, pp. 2088-2100; 30 January 1935, no. 150, pp. 5936-55; 9 October 1935, no. 239, p. 9787; 6 December 1935, no. 274, p. 11194.

${ }^{29}$ According to Jackson (1965, p. 94), "the areas [the Basque region and Andalusia] most dependent on international commerce were simultaneously making the most articulate demands on the new regime."
} 
those from Murcia championed export credits for fruit growers; on the other, parliamentarians from industrial Catalonia demanded stricter tariffs and a quota system on imports of manufactured goods, while those from Andalusia sought assistance for wheat and rice farmers. The protectionists were in the minority. In April 1934, Inadalecio Prieto, the Socialist deputy from the Basque region, and formerly a prominent cabinet minister in the Azaña coalition, summarized the debate's outcome: "In my opinion and surely that of all the deputies, we are going to inaugurate - and if not to initiate to strengthen - a policy of exchange of products." 30

The policy was adopted in a trial and error manner and remained active during the more conservative second biennium that commenced with the election of a new government in December $1933 .{ }^{31}$ Owing to the collapse of world trade, the number of MFN agreements actually fell from 64 in 1922-1929 to 34 in 1931-1936. But the decline masks a change in their nature. ${ }^{32}$ The treaty with Italy that came into effect in March 1932 was a harbinger of the new strategy. The two countries conceded (conditional) MFN treatment upon specified lists of articles (Jones 1934, p. 59). Spain applied the second column tariff rates, but a special lower tariff was accorded on some products in an annexed list. The objective of the treaty was to permit the entry of a handful of goods in order to gain a foothold in the Italian market for selected Spanish items. Treaties with the Netherlands, Poland, and Romania were renegotiated along these lines. In exchange for market access, Germany granted in 1933 special tariffs on imports of Spanish tomatoes and fig extracts used in the production of tobacco. In 1935 the list of goods widened even as Germany adopted stringent exchange controls. With France in 1933, Spain reduced duties on champagne, cognac, and Armagnac, among other spirits, receiving assurance of market entry for wine and fish exports. ${ }^{33}$

\footnotetext{
${ }^{30}$ Spain, Diario de Sesiones, 6 April 1934, no. 64, pp. 2088-2100. Prieto was Minister of Finance of the provisional government (established in August 1931) during the financial crisis. As Minister of Public Works between 1931 and 1933, Prieto oversaw major infrastructure projects (Velarde 2010).

${ }^{31}$ On the second biennium, see Payne (1993) and Preston (1994). Saz (1985) claims that the turnover of trade negotiators after 1933 was negligible. There was no formal vote along party lines on policy, but there was discussion and approval of individual treaties. See Table A2 in the Online Appendix.

${ }^{32}$ Authors' calculations. See Online Appendix D for details.

${ }^{33}$ El Financiero (12 January 1934, pp. 47-52; 14 February 1935) described the contents of several treaties. An agreement with France in 1934 and subsequently other countries established a certificate of origin label distinguishing Spanish wines from seemingly comparable but inferior foreign wines. At a minimum, Richmond (1987, p. 369) observes, "bilateral commercial agreements allowed Spain to maintain her gold reserves."
} 
In late 1931 the government authorized quotas that were applied in trade agreements beginning in 1933. These measures fixed the value or volume of specific imported items. Quotas in the mid-1930s had become widespread on the continent, especially among gold bloc countries (League of Nations 1942, p. 138; Harberler 1943). In Spain, quotas met with a mixed reception. Again ideas and interests mattered. Ceballos Teresí, an antiRepublican and director of El Financiero, the country's leading economics periodical, supported quotas. But his opinion was in the minority. Badía, the Catalan deputy, rejected the use of quotas since trading partners would have interpreted these types of restrictions as discriminatory, adopting their own retaliatory measures in turn (El Financiero, 12 January 1934, pp. 47-52). Spain did not have the resources to handle the inevitable negotiations and avert a trade war. Rafael Salgado, President of the Madrid Chamber of Commerce (El Financiero, 19 March 1935, p. 326), echoed these views. In the end, Spain appears to have used quotas sparingly, only 48 goods had import limits (Viñas et al. 1979). ${ }^{34}$ Occasionally Spain embedded quantity controls in treaties such as with France (March 1934), Ireland (June 1934), and the Netherlands (December 1934). Quotas fixed in treaties were fewer in number and less restrictive than stand-alone quotas. Authorities made these concessions in the expectation that trading partners would reciprocate and open their markets to Spanish goods.

How successful was the Republic's policy to secure foreign market access? Did it actually mark a change in direction? During the election of 1933, Fernando de los Ríos, a Socialist minister in the Azaña government, campaigned on the policy's achievements. He claimed that the decline in Spanish exports since 1929 was half that of France (Irwin 1991, p. 41). The overall trade balance in Figure 1 did, in fact, stabilize in 1932 and 1933 but declined thereafter; Jackson (1965, pp. 86-87) attributed slack export growth in the period to faulty and incoherent planning. The trouble is that aggregate evidence masks the likelihood that surpluses and deficits shifted across countries. The remaining parts of this paper address this concern. We first introduce a novel granular trade dataset of exports and imports. Next, we decompose the value of trade into intensive and extensive margins. Then exploiting the variation in tariffs, MFN accords, and quotas, we evaluate the effects of specific policies on the margins of trade.

\footnotetext{
${ }^{34}$ France had quotas on 35 goods, the most of any country. See Table A2 in the Online Appendix for quotas by country and product category. The official policy was forthright: "The government is the enemy of the quota regime and prefers commercial freedom instead; but if other countries use quotas as a weapon, we see ourselves compelled to use them as well." Spain, Diario de Sesiones, 30 January 1935, no. 150, p. 5953.
} 


\section{A GRANULAR LOOK AT SPANISH IMPORTS AND EXPORTS,} 1922-1935

\section{Constructing the Dataset}

We collected information on imports and exports from the Estadistica del Comercio Exterior de España (Consejo de Economía Nacional 1922 1928, Ministerio de Hacienda 1929-1935). For imports, we retrieved data for 1922, 1925, 1928, 1931, 1933, and 1935. The years cover the major turning points in the international economy and Spanish trade policy. On the import side, we have culled information on 1,540 items or categories; we have added information on items occasionally reported in the official statistics for a maximum of 1,720 items. After the 1922 tariff revision, the identity of products remained unchanged. But since goods were recorded at different degrees of granularity, corresponding to what came to be defined as the SITC 5, 4, or 3-digit levels, we classified products using the 3-digit SITC classification to ensure a harmonized dataset of goods in our econometric work. ${ }^{35}$ The reduction in the number of items is offset by the gains in using a consistent group of products for estimating the contributions of the various policy measures on trade in different time periods and across different sectors of activity. Meissner and Tang (2018) adopt this procedure. The Estadistica gives information on 93 import sources, corresponding to 81 trading countries. ${ }^{36}$ The top panel of Table 2 summarizes the sample. The fluctuations in trade in Column (1) mirror Tena's (2005) series; the last column conveys the strong deflationary pressures of the period.

On the export side, we have collected data for 1928 and 1935. Before 1928 , the official sources provide information at the good-country level for 350 items only. For the period after 1928, we have information on 1,540 potential items, the same number as imports. But the number of goods actually exported was considerably less (Table 2 bottom panel). We retrieve this information for the 10 most important export destinations, which amounted to 83.2 percent of the value of exports in 1928 and 76.4 percent in 1935 . We restrict the years for which we collect export data because of the narrow range in products and markets. The decline in exports reported in the first column of the bottom panel is in line with Tena's (2005) figure of a contraction of 66.2 percent in the same period. The last column confirms the collapse in agricultural export prices.

\footnotetext{
${ }^{35}$ The 3-digit SITC (revision 4) classification comprises 262 categories. For the regression analysis, we use a sample of 253 products.

${ }^{36}$ The regressions are limited to 47 countries because of the availability of GDP estimates. We rely on the calculations of Klasing and Milionis (2014).
} 
TABLE 2

SPANISH IMPORTS AND EXPORTS: VALUES AND NUMBER OF GOODS, 1922-1935

\begin{tabular}{|c|c|c|c|c|c|}
\hline \multicolumn{6}{|c|}{ Imports } \\
\hline Year & $\begin{array}{l}\text { Total Imports } \\
\text { (mill. gold ptas) }\end{array}$ & $\begin{array}{l}\text { Percentage } \\
\text { Growth }\end{array}$ & $\begin{array}{l}\text { Goods } \\
\text { with Positive } \\
\text { Imports }\end{array}$ & $\begin{array}{c}\text { Countries } \\
\text { with Positive } \\
\text { Imports }\end{array}$ & $\begin{array}{l}\text { Average } \\
\text { Values of } \\
\text { Imports }\end{array}$ \\
\hline 1922 & 2274.59 & & 1477 & 70 & 1.54 \\
\hline 1925 & 2097.81 & -7.77 & 1486 & 76 & 1.41 \\
\hline 1928 & 2819.62 & 34.41 & 1501 & 86 & 1.88 \\
\hline 1931 & 1137.96 & -59.64 & 1519 & 86 & 0.75 \\
\hline 1933 & 808.98 & -28.91 & 1482 & 89 & 0.55 \\
\hline 1935 & 850.21 & 5.10 & 1508 & 90 & 0.56 \\
\hline
\end{tabular}

Exports

\begin{tabular}{cccccc} 
Year & $\begin{array}{c}\text { Notal Exports } \\
\text { (mill. gold ptas) }\end{array}$ & $\begin{array}{c}\text { Percentage } \\
\text { Growth }\end{array}$ & $\begin{array}{c}\text { Guods } \\
\text { with Positive } \\
\text { Exports }\end{array}$ & $\begin{array}{c}\text { Goods } \\
\text { with Positive } \\
\text { Exports } \\
10 \text { countries }\end{array}$ & $\begin{array}{c}\text { Average } \\
\text { Values of } \\
\text { Exports }\end{array}$ \\
\hline 1928 & 2182.71 & & 931 & 675 & 2.34 \\
1935 & 590.10 & -72.97 & 1003 & 643 & 0.59 \\
\hline
\end{tabular}

Notes: Average values of imports and exports are total values divided by the number of products in million gold pesetas. For imports, we consider 93 sources. For exports, the total number of goods refer to all countries including the 10 leading export destinations of Spain (Argentina, Belgium, France, Germany, Italy, the Netherlands, Sweden, Switzerland, United Kingdom, and the United States). See Online Appendix A for details.

Sources: Spain, Consejo de Economía Nacional (1922-1928), Ministerio de Hacienda (1929-1935).

As for our policy variables, we have taken from official Spanish sources information on tariffs, quotas, and MFNs, at the good and country level wherever feasible. Online Appendix A gives more detail on our dataset and sources.

The discrepancy between our samples of imports and exports and relevance for our policy variables merit discussion. To begin, we are dependent on the sources available. But the fact is there was a greater number of imported goods delivered by a greater number of countries than comparable figures for exports, which were restricted to a handful of agricultural products and destinations. ${ }^{37}$ As for policy, we are interested in the various measures adopted to protect domestic economic activity and

${ }^{37}$ A further distinction is that imports were recorded as c.i.f. values and exports as f.o.b. As a result, we have information on prices of goods sold in Spain, but not abroad. 
those measures, like MFNs and quotas, that conceded domestic market access for exposure abroad. ${ }^{38}$ For this purpose, the Spanish sources provide information on tariff rates on imports at the good level, as well as items covered in MFN agreements. On the export side, this type of information is commonly available in foreign sources only. That said, the years for which we have export data provide meaningful information on changes in policies between the late 1920s and the mid-1930s. Finally, the general research practice is to study either exports (Huberman, Meissner, and Oosterlinck 2017; Meissner and Tang 2018) or imports (Betrán and Huberman 2016; de Bromhead et al. 2019a, 2019b). In this regard, our paper is innovative in that we have compiled data for both.

Figures 2-5 summarize our sample of imports and exports. In line with the preferences of emerging interest groups, the establishment of the Republic saw a shift in the type of products imported based on our classification at the 1-digit SITC level (Figure 2). The demand for basic manufactures declined after 1928, but that for intermediate goods like chemicals, crude materials, and machinery and transport equipment increased, with the exception of the Depression years. Consumer or final good imports represented in the figure by miscellaneous manufactures rose steadily after 1931. Alongside the changing composition of goods, sources of imports shifted (Figure 3). After 1928, Belgium, Germany, and the United States grew their shares of the Spanish market; beginning in 1931 that of France and Argentina - and all of Latin Americacontracted. The British share declined from 1922 to 1928 and then stabilized. Later we investigate whether the diversion in trade was a consequence of bilateral trade policies.

As for exports, our sample confirms the preeminent role of agricultural goods (Figure 4). The share of agricultural exports increased from 32.5 to 46.7 percent, whereas that of basic manufactures dropped from 19.0 to 12.4 percent. Regarding destinations, the adjustment in market shares suggests a diversion in trade in line with that of imports (Figure 5), the portion of France contracting, while that of the United States, Germany, and Belgium improving. Interestingly, despite the collapse in the citrus market, Spanish exports to the United Kingdom actually improved, El Financiero (29 March 1935, 30 April 1935) reporting renewed demand for wine, olive oil, and tin. Finally, shipments to Latin America declined.

\footnotetext{
${ }^{38}$ De Bromhead et al. (2019b, p. 332) adopt a comparable stance. The United Kingdom privileged Imperial imports because they "wished to improve their access to Dominion markets, and retain a margin for maneuverer [sic] when it came to potential future trade agreements with foreign countries."
} 


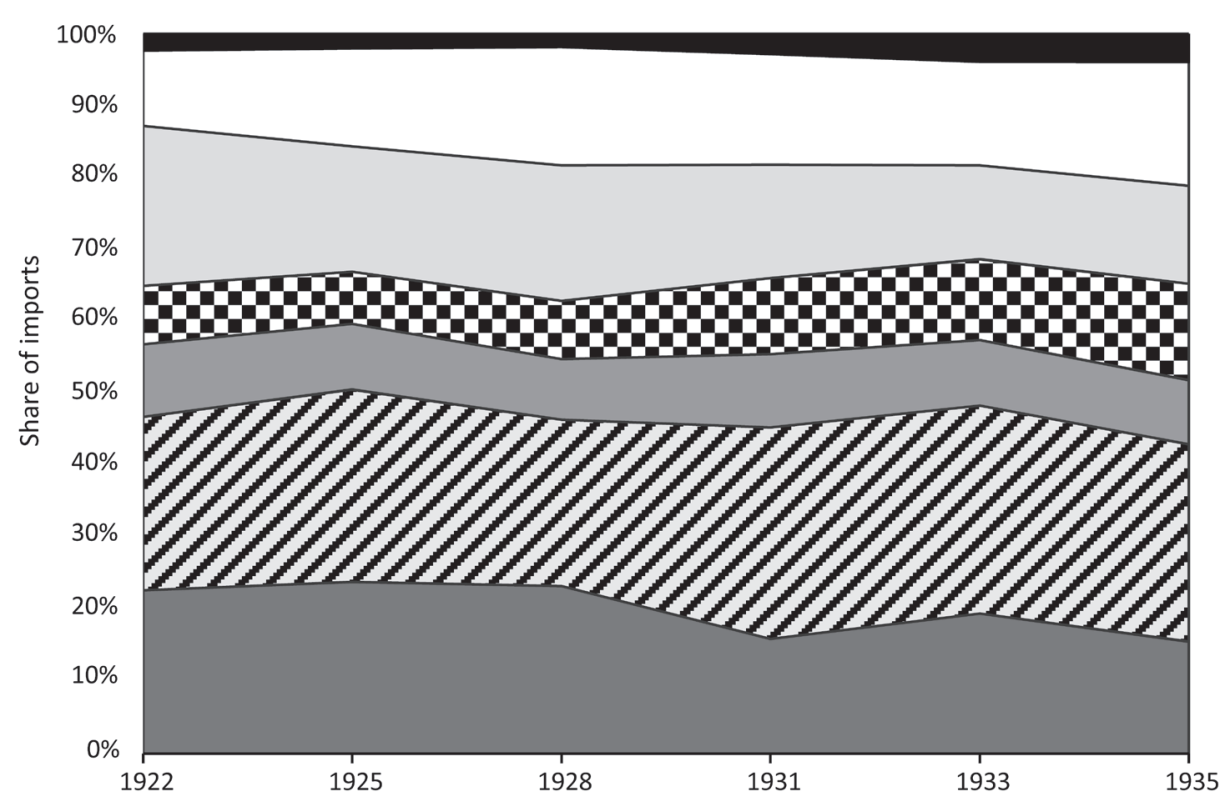

口Food and live animals

a Crude materials and inedibles

$\square$ Mineral and fuels

$\square$ Chemicals and related products

$\square$ Basic manufactures

$\square$ Machinery and transport equipment

- Miscellaneous manufactured articles

FIGURE 2

IMPORTS BY PRODUCT AT THE 1-DIGIT SITC LEVEL, 1922-1935

Sources: Spain, Consejo de Economía Nacional (1922-1928), Ministerio de Hacienda (1929-1935).

Lacking Imperial connections and handicapped by disinterested colonial offshoots, Spain became more dependent on European trading partners, with the exception of the United States.

\section{Decomposing the Margins of Trade}

In this section, we decompose the value of trade into intensive and extensive components. The intensive margin captures changes in trade that occurred, usually in the short-term, in preexisting or continuous relationships; the extensive margin captures changes in trade in new items and with new trading partners. Changes in variable trade costs, like tariffs, affected both margins, but changes in fixed-trade costs attributed to the signing of MFN accords that resulted in the expansion or contraction of market access affected the extensive margin exclusively. At a crude level 


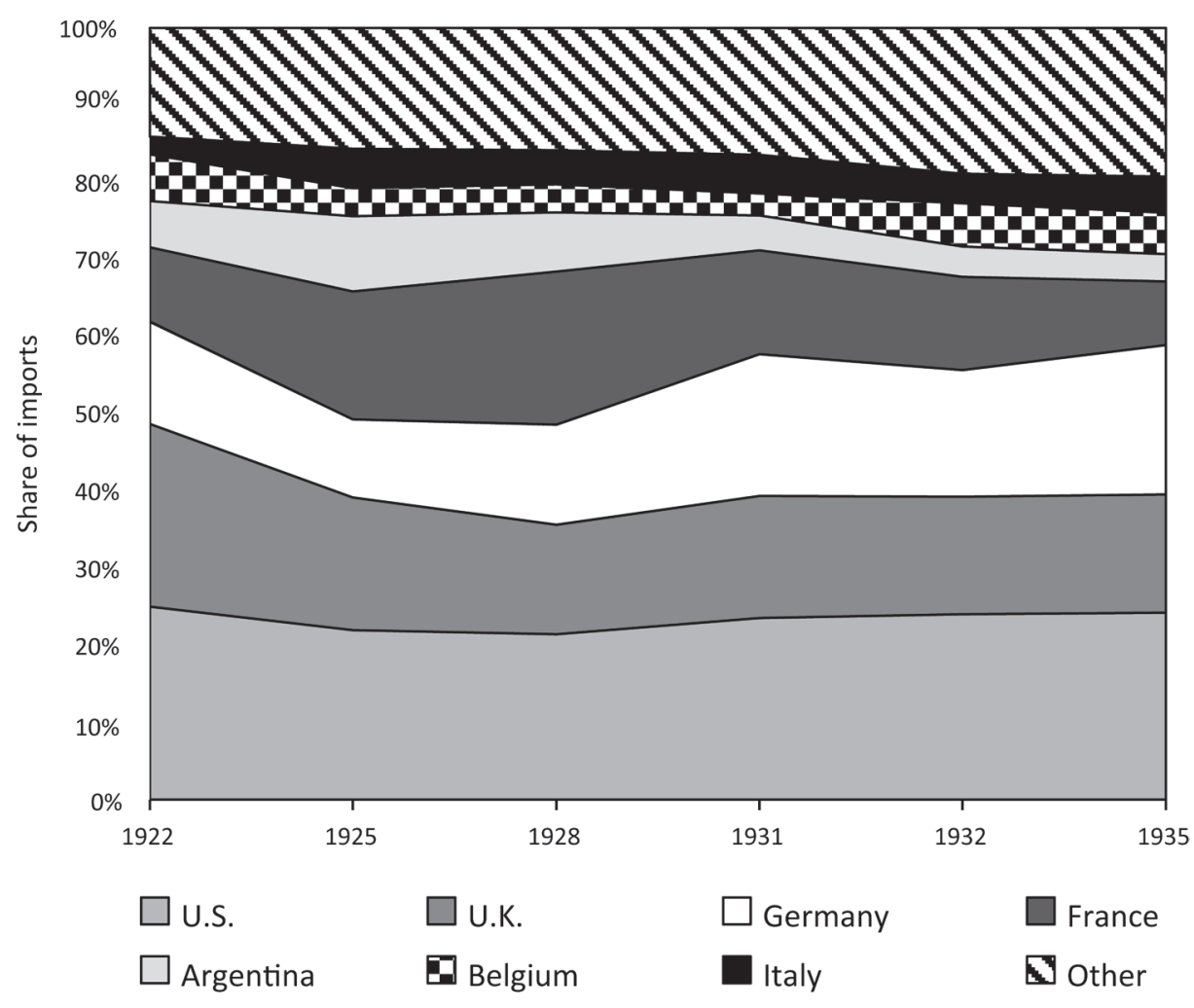

FIGURE 3

IMPORTS BY SOURCE, 1922-1935

Notes: Other countries are British Asia, the Netherlands, Sweden, and Switzerland.

Sources: Spain, Consejo de Economía Nacional (1922-1928), Ministerio de Hacienda (1929-1935).

of aggregation summarized in Table 1, the 1930's trade collapse does not reveal itself in a substantial change in the number of products imported and exported or in the number of source and destination countries. Does this result hold at a finer level of disaggregation?

To motivate the presentation, consider the number of import and export products traded at the country level in Figures 6 and 7. The correspondence in the number of imported and exported items meshes with our claim that Spain exchanged markets at home for access abroad. For France, the number of goods traded declined between 1933 and 1935, but for Italy and the United States, imported and exported items moved together.

Table 3 presents an exhaustive decomposition of changes in the value of trade into intensive and extensive margins. Here we follow Eaton et al. (2007) and Meissner and Tang (2018). We are restricted to the value of 


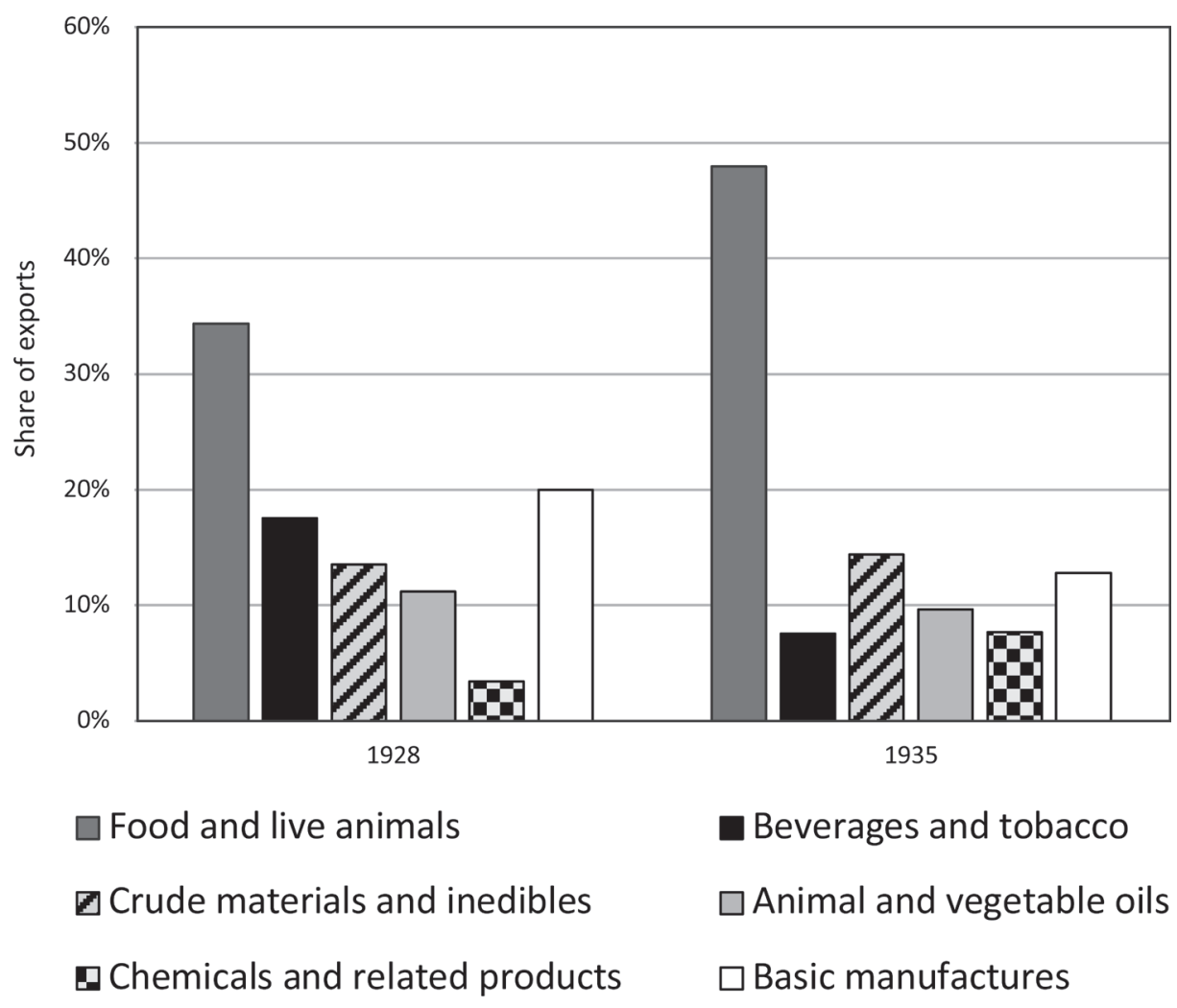

FIGURE 4

EXPORTS BY PRODUCT AT THE 1-DIGIT SITC LEVEL, 1928 AND 1935

Sources: Spain, Consejo de Economía Nacional (1922-1928), Ministerio de Hacienda (1929-1935).

imports for which we have detailed information over a number of years. Online Appendix B gives a full description of our procedure. We subdivide the change in trade into three subperiods, the overall contraction being in the order of 63 percent, and categorize the change in imports by type of good and country. We separate continuous or incumbent goods, new items that were previously not traded, and old goods that exited trade permanently. As for countries, we distinguish those sources having previously engaged in the import activity of Spain from new countries and countries that stopped trading entirely. ${ }^{39}$ These categories are informative

${ }^{39}$ From 1922-1935, 58 countries had continuous trading relationships with Spain (old and new continuous sources in the table). For the same period, 23 countries (new countries in the table) commenced trading with Spain, including Australia, Bolivia, Canada, Ireland, Poland, and South Africa. Panama was the sole (old) country permanently exiting trade, excluding Portuguese possessions in Asia and Danish possessions in Europe. 


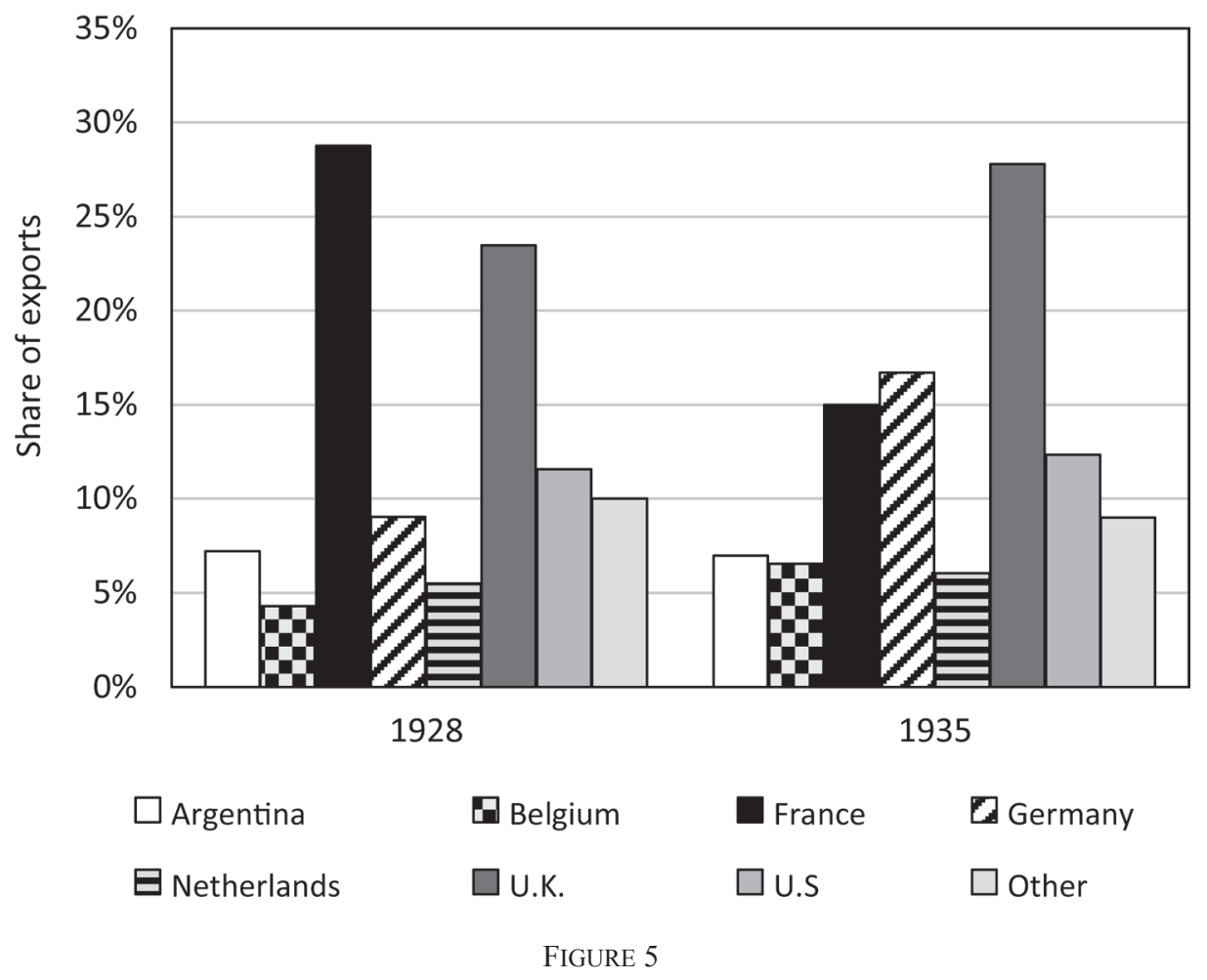

EXPORTS BY DESTINATION, 1928 AND 1935

Notes: Other countries are Italy, Sweden, and Switzerland.

Sources: Spain, Consejo de Economía Nacional (1922-1928), Ministerio de Hacienda (1929-1935).

because the incidence of tariffs, MFNs, and quotas varied across countries and goods.

Our method of decomposition considers various combinations of goods and countries. We use information on approximately 1,720 goods in this exercise and for 93 import sources corresponding to 81 countries. Lines 1-3 represent the contribution of growth in continuous goods. These consist of continuous imports from continuous partners (line 1) and imports of the same goods from new sources and new countries (lines 2 and 3). For instance, Spain imported textile machinery from the United Kingdom throughout the period; in 1935, Japan and Sweden emerged as new sources, and Ireland a new country exporting machinery. We retrieved 3,045 good-country combinations of this type for the entire period and 2,883 combinations for the subperiod 1931-1935. Lines 4 and 5 represent goods Spain ceased importing from continuous partners and countries terminating trade entirely. Spain dropped imports of certain fruits and vegetables from France in 1935. All total, this group 


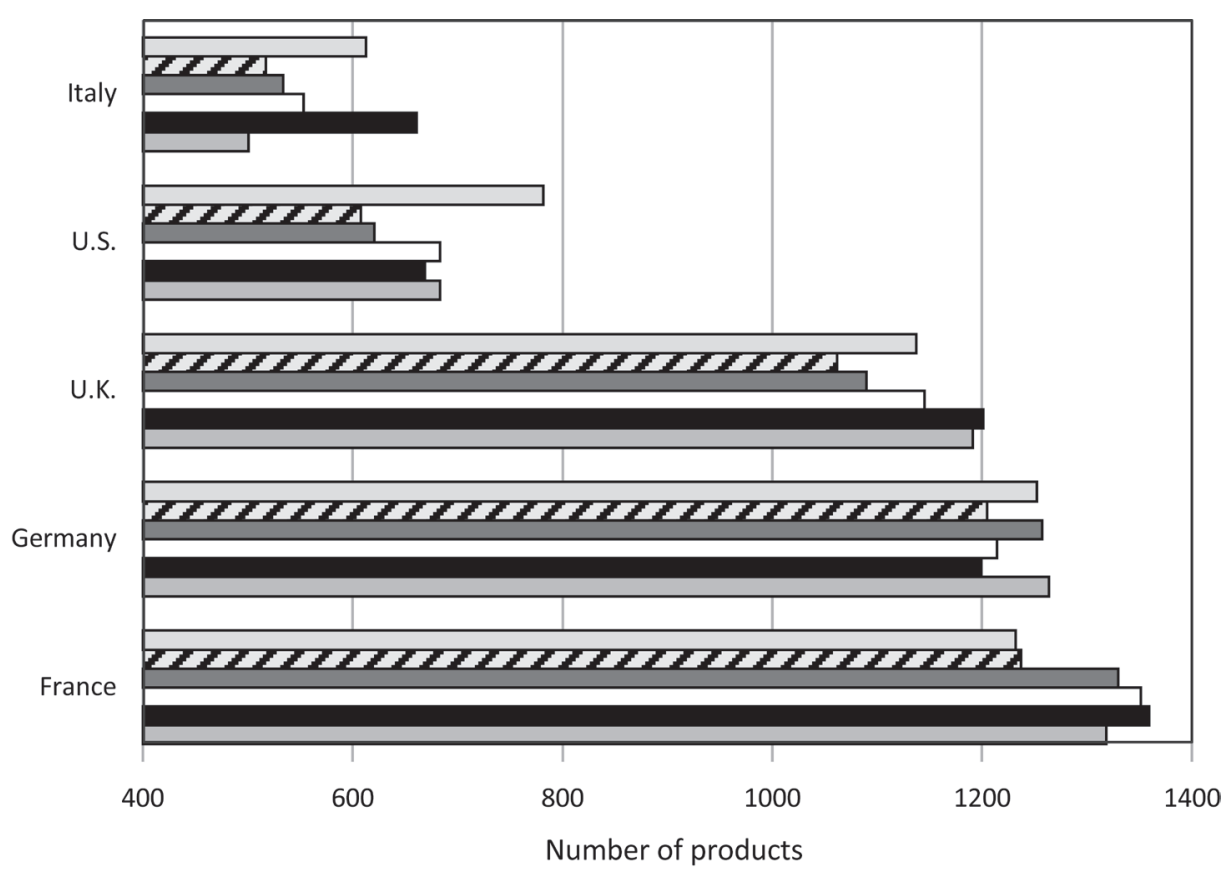

$\square 1935 \square 1933 \quad \square 1931 \quad \square 1928 \quad \square 1925 \quad \square 1922$

FIGURE 6

NUMBER OF IMPORTS BY COUNTRY, 1922-1935

Sources: Spain, Consejo de Economía Nacional (1922-1928), Ministerio de Hacienda (1929-1935).

comprised 2,512 good-country combinations for 1922-1935 and 1,909 for 1931-1935. The remaining lines report new and exiting goods. Lines 7 and 8 consist of the addition of new goods defined as goods never previously traded either by continuous or new countries. After 1931, we found 188 items of this type, such as handsaws from the United States, Belgian bicycle accessories, and Austrian photographic paper. Lines 10 and 11 summarize the contribution of exiting goods from all sources. After 1931, these consist of 163 items, including Danish dairy cream, German sugar beet, and Algerian rice.

For our purposes, we define line 1 as the intensive margin; the extensive margin combines lines $2-5,7,8,10$, and $11 .^{40}$ Over the entire period,

${ }^{40}$ Eaton et al. (2007) define the intensive margin as lines 1-5, or changes in all types of continuous goods, regardless of origin. Using this definition, for the period 1922-1935, the intensive margin explains more than 100 percent of the fall in trade; the extensive margin is only slightly positive. These results hold for subperiods, except for 1922-1928, in which there is a considerable movement of new and exiting goods. By this accounting, the sizeable intensive margin during the Depression, 1928-1935, aligns with the standard view that the fall in trade was the consequence of the steep fall in income. 


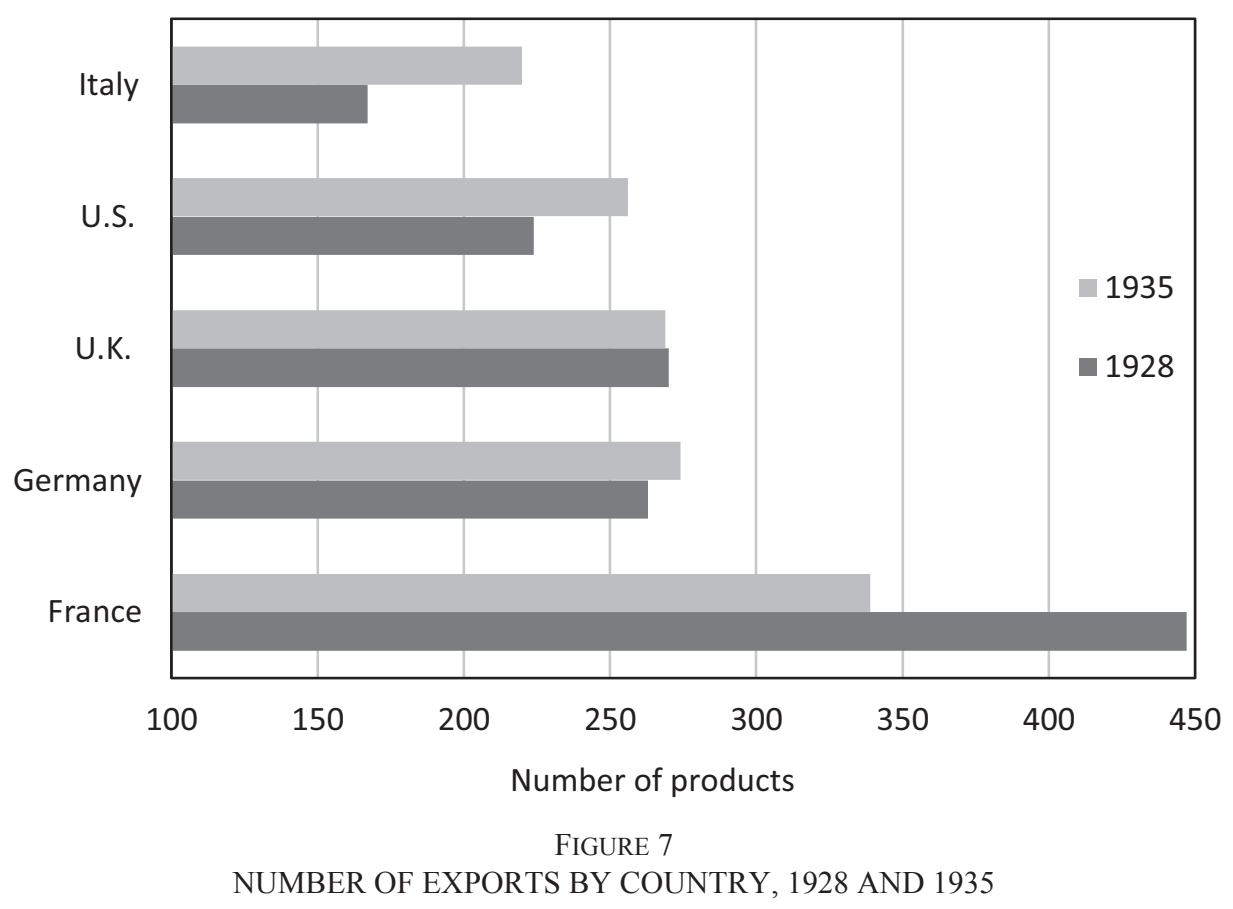

Sources: Spain, Consejo de Economía Nacional (1922-1928), Ministerio de Hacienda (1929-1935).

84.05 percent of the decline in trade can be attributed to the change in the value of trade in continuous relationships (goods and countries). But the contribution of the extensive side was non-negligible. Lines 2-5 comprise the effects of unconditional and conditional MFN treaties and quotas. Since these policies affected market access, they ought to be recorded as components of the extensive margin. Line 4 alone conveys that the exit of continuous goods from old sources to the decline in trade between 1922 and 1935 was 26.38 percent.

Lines 14 and 15 sum up the intensive and extensive margins. Since the various components of the extensive side tend to offset each other, the absolute figures (reported in Columns (2), (4), (6), and (8)) provide a more meaningful measure of the changes in countries and products. The absolute changes imply a considerably large share of trade explained by the extensive margin. For the entire period, the extensive margin is about half the size of the intensive side. ${ }^{41}$ The distinction between the 1920s and 1930s is interesting in this regard. The extensive margin for 1922-1928 was the outcome of an upswing in Spanish demand for continuous goods

${ }^{41}$ Using a similar procedure, Meissner and Tang (2018) report a relatively large extensive margin for Japan between 1880 and 1910. 


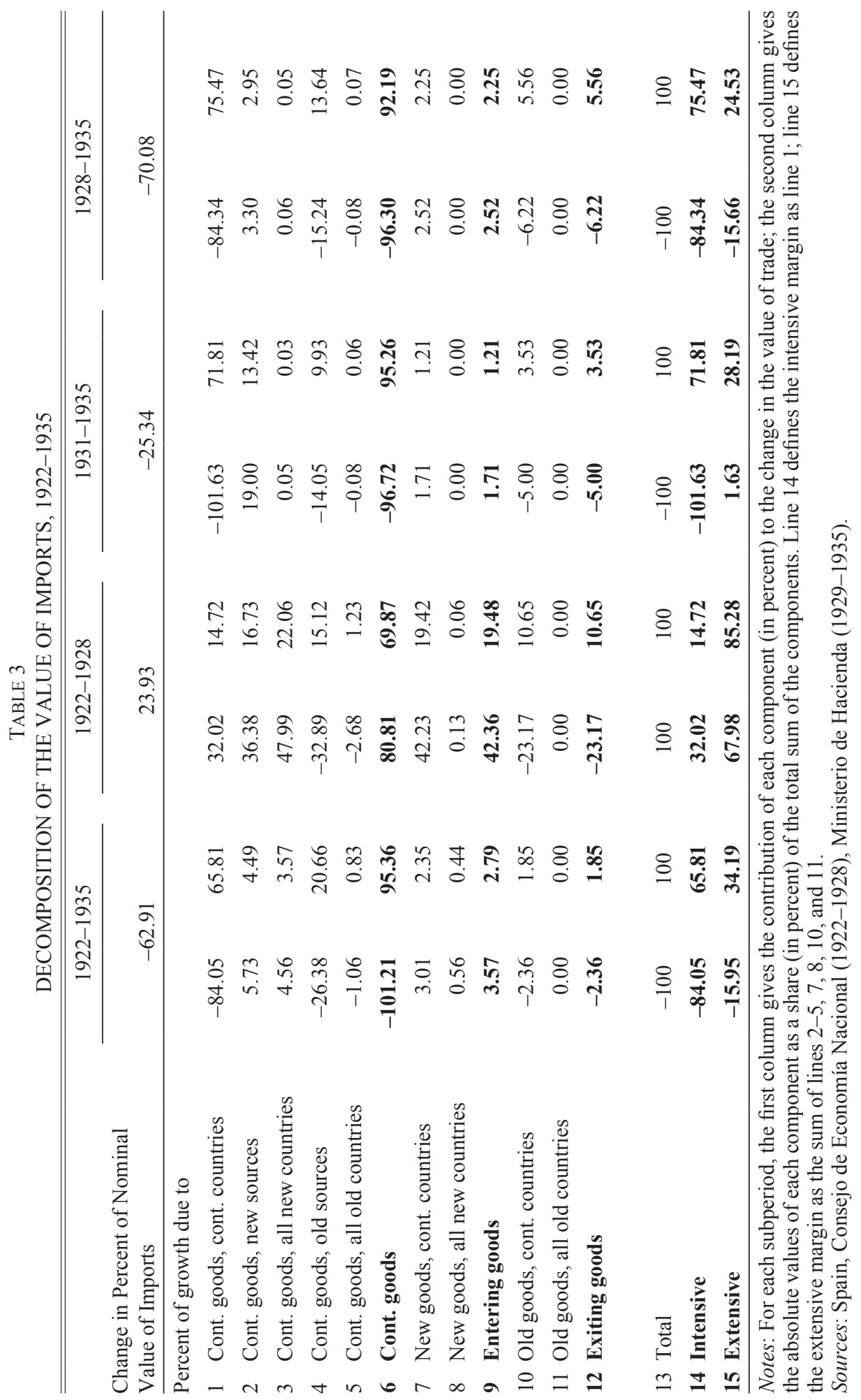


(lines 2 and 3). Early in the decade, the emergence of new sources and countries in the trade recovery supplied these goods. Later in the decade, the adoption of unconditional MFNs was an added source of imports. In the post-Depression years, continuous partners ceased shipping some of these goods because they were not specified in conditional MFN treaties or because other sources supplied these imports. The increase in the number of Italian goods after signing an MFN shows up in the positive value in line 2 for 1931-1935. For the same period, the negative value in line 4 captures the effect of MFNs in diverting trade from France, Portugal, and Argentina, among others. The upshot is that these net additions in the extensive margin lend credence to our claim that trade policy mattered.

\section{DID TRADE POLICY MATTER? \\ A CLOSER LOOK AT THE MARGINS OF TRADE}

Our overview of trade policy has emphasized the heterogeneity in policies across goods and countries. We brought further attention to the change in policy direction after the establishment of the Second Republic. The dictatorship relied on tariff policy and unconditional MFNs beginning in 1927. The new regime, while not forsaking tariffs, the two-column structure remaining in place, turned to conditional MFNs and quotas in treaties to secure markets for Spanish exports in return for entry at home. Again, these policies were not uniform across goods and countries. Exploiting this variation, we study the effectiveness of trade policies on exports and imports at intensive and extensive margins. We begin with imports for which we have detailed information.

\section{Imports: The Intensive Margin}

We apply the standard gravity model of John Anderson and Eric van Wincoop (2003) and João Santos Silva and Silvana Tenreyro (2006) to study the effect of policy on the intensive margin. ${ }^{42}$ In this framework, bilateral trade flows between two countries increase with the size of countries, approximated by their GDP, and decrease with the distance between trading partners and factors that create multilateral trade resistance or trade costs. We adapt the model to consider disaggregated imports of the

\footnotetext{
${ }^{42}$ In our regression analysis, we define the intensive margin as the value of goods imported, which approximates the value of trade in continuous goods and with continuous partners. The extensive margin corresponds to the number of products.
} 
destination country (Spain). For our purposes, trade resistance factors comprise tariffs, exchange rates, MFN clauses, and quotas by product and country.

Our estimating model is, therefore:

$$
M_{g c t}=Y_{c t}^{\alpha} x_{c}^{\beta}\left(1+t_{g c t}\right)^{\gamma} E_{c t}^{\delta} \exp \left(M F N_{g c t} \phi+Q_{g t} \lambda+Q_{g c t} \mu\right) \eta_{g c t}
$$

In this exercise, we approximate the intensive margin, $M_{g c t}$, by the value of imports of each good $g$ from country $c$ to Spain in year $t ; Y_{c t}$ is the GDP of country $c$ in year $t ; x_{c}$ comprise the time-invariant trade resistance variables, such as distance, border country, language, and colony of another country; $t_{g c t}$ is the ad-valorem tariff of good $g$ and country $c$ in year $t$, calculated as the specific duty rate divided by the unit value (which in turn is the import value divided by import quantity); and $E_{c t}$ is the exchange rate defined as the peseta value of country $c$ 's currency in year $t$. We code $M F N$ in two ways. At the finest disaggregated level (a maximum of 1,720 products), the variable equals 1 if a MFN clause exists for a good $g$ and country $c$ in year $t$, and 0 if no clause exists; in regressions using the 3-digit SITC classification, the variable takes the value of the number of items in a specified MFN treaty as a fraction of the total number of items in the relevant SITC category. Finally, we coded two types of quotas: quotas applied to certain goods and usually based on the previous year's imports $Q_{g t}$, and quotas negotiated in trade treaties for select countries, $Q_{g c t}$. Analogous to the $M F N$ variable, $Q_{g t}$ and $Q_{g c t}$ take a value of 1 (quota) or 0 (no quota). In Equation (1), $\alpha, \beta, \gamma, \delta, \phi, \lambda$, and $\mu$ are unknown parameters. ${ }^{43}$

We estimate the log-linearized version of Equation (1):

$$
\begin{aligned}
\ln \left(M_{g c t}\right)=\alpha \ln \left(Y_{c t}\right) & +\beta \ln \left(x_{c}\right)+\gamma \ln \left(1+t_{g c t}\right)+\delta \ln E_{c t}+\phi M F N_{g c t} \\
& +\lambda Q_{g t}+\mu Q_{g c t}+d_{g t}+d_{g c}+\ln \left(\eta_{g c t}\right) .
\end{aligned}
$$

In the logarithmic form, OLS estimated coefficients have two problems. First, OLS does not account for zero import flows or zero values because of rounding. Second, OLS does not correct for heteroskedasticity that is present in trade data. For these reasons, Santos Silva and Tenreyro (2006) adopt a Poisson pseudo-maximum likelihood (PPML) estimator with the dependent variable in levels. Along the lines of Anderson and van Wincoop (2003), we augment the conventional trade equation. Since

${ }^{43}$ The multiplicative stochastic term $\eta_{i j}$ with unit conditional mean, $E\left(\eta_{g c t} / Y_{c t}, x_{c}, t_{g c t}, E_{c t}\right.$, $\left.M F N_{g c t}, Q_{g t}, Q_{g c t}\right)=1$, is assumed to be statistically independent of the regressors. 
we have information on Spain only, we are unable to include time-varying multilateral resistance terms of the source country. Instead, we include good $x$ country fixed effects, $d_{g c}$ This term controls for a positive spurious correlation between imports and tariffs, and imports and trade quotas, for instance. We add in the equation good $x$ year fixed effects, $d_{g t .}$ This term controls for demand and supply shocks affecting trade partners and, hence, for total imports of a given good in a given year. ${ }^{44}$ The inclusion of these fixed effects implies that time-invariant trade resistance variables drop out of our estimating regression. ${ }^{45}$

Of special interest is the relationship between tariffs and MFNs. We conjecture that the regime of Primo de Rivera relied on tariffs and to a lesser extent MFNs; the obverse would have held during the Second Republic. While the adoption of MFNs entailed occasionally the adjustment of tariffs, authorities after 1931 used them as distinct policy instruments. In many instances, they made tariff changes reactively, often in response to hikes in duties or devaluation elsewhere, but negotiated MFNs proactively, with the intent of expanding market access. Although there was inevitable overlap, tariffs and MFNs were applied to different sets of goods and countries. We test for the independence of MFNs later. As for other policy instruments, we anticipate that quotas would have restricted imports, but the combination of treaties and quotas encouraged them because they signaled to trading partners Spain's willingness to pursue or establish a continuous relationship. Spain would negotiate specific quotas on imports in favor of export concessions.

The matter of reverse causation merits further discussion. Since treaties and tariffs are not randomly distributed, coefficient estimates could be biased (Santos Silva and Tenreyro 2010). It may well be that countries sign agreements with trading partners because of related or mutual characteristics, such as a shared border, language, or some common historical connection, for instance, colonial links, or that countries are pressured to establish stricter tariffs on goods that they have imported on a large scale in a previous year. That said, these conditions do not seem to bear on the Spanish case because of the loss of empire and because of the country's small share in most export markets, excluding citrus. Exceptionally, the across-the-board tariff changes in 1930 aimed to restrict imports from the United States. But even in this case, other factors contributed to the adoption of retaliatory measures. Since tariffs were specific, their incidence

\footnotetext{
${ }^{44}$ With good $x$ year fixed effects, we control for changes in 1931 concerning the manner unit values were recorded. See Online Appendix A for details.

${ }^{45}$ In the presence of two high-dimensional fixed effects in a Poisson framework, we employ the Stata estimator poi2hdfe (Guimaraes and Portugal 2010).
} 
TABLE 4

THE EFFECT OF TRADE POLICY ON IMPORTS, 1922-1935

\begin{tabular}{|c|c|c|c|c|c|c|}
\hline & (1) & (2) & (3) & (4) & (5) & (6) \\
\hline & $1922-1935$ & $1922-1928$ & $1931-1935$ & $1931-1935$ & $1931-1935$ & 1931-1935 \\
\hline Log (GDP exporter) & $\begin{array}{c}0.347 \\
(0.371)\end{array}$ & $\begin{array}{l}0.0877 \\
(0.660)\end{array}$ & $\begin{array}{c}0.140 \\
(0.407)\end{array}$ & $\begin{array}{c}0.252 \\
(0.408)\end{array}$ & $\begin{array}{c}0.091 \\
(0.449)\end{array}$ & $\begin{array}{c}0.190 \\
(0.444)\end{array}$ \\
\hline $\log (1+$ tariff $)$ & $\begin{array}{c}-1.141 * * * \\
(0.432)\end{array}$ & $\begin{array}{c}-1.881 * * * \\
(0.597)\end{array}$ & $\begin{array}{c}-0.0456 \\
(0.388)\end{array}$ & $\begin{array}{c}0.277 \\
(0.323)\end{array}$ & $\begin{array}{l}-0.005 \\
(0.390)\end{array}$ & $\begin{array}{c}0.285 \\
(0.339)\end{array}$ \\
\hline MFN & $\begin{array}{c}-0.0489 \\
(0.158)\end{array}$ & $\begin{array}{l}-0.171 \\
(0.121)\end{array}$ & $\begin{array}{l}0.500 * * * \\
(0.149)\end{array}$ & $\begin{array}{c}0.560 * * * \\
(0.162)\end{array}$ & & \\
\hline Log (exchange rate) & $\begin{array}{l}-0.287 \\
(0.177)\end{array}$ & $\begin{array}{c}-0.415 * \\
(0.252)\end{array}$ & $\begin{array}{c}-0.409 * \\
(0.218)\end{array}$ & $\begin{array}{c}-0.390 * \\
(0.216)\end{array}$ & $\begin{array}{c}-0.361^{*} \\
(0.219)\end{array}$ & $\begin{array}{c}-0.340 * \\
(0.219)\end{array}$ \\
\hline Quota & & & & $\begin{array}{l}-1.270 \\
(1.149)\end{array}$ & & $\begin{array}{l}-1.362 \\
(1.120)\end{array}$ \\
\hline Quota in treaty & & & & $\begin{array}{c}1.008 * * * \\
(0.361)\end{array}$ & & $\begin{array}{c}0.896 * * * \\
(0.397)\end{array}$ \\
\hline Observations & 19,645 & 8,135 & 8,546 & 8,546 & 8,546 & 8,546 \\
\hline
\end{tabular}

Notes: Dependent variable is the value of imports by good, country, and year. Poisson Pseudo-Maximum Likelihood (PPML) estimation using Stata estimator poi2hdfe. Estimates control for good*country and good*year fixed effects. Robust standard errors clustered by country in parentheses. ${ }^{* *} \mathrm{p}<0.01,{ }^{* *} \mathrm{p}<0.05,{ }^{*} \mathrm{p}<0.1$

Source: See Online Appendix A.

was determined by the (world) price level. As for MFNs, they were often driven by geopolitical factors and thus independent of the previous value of imports.

In Table 4, we report estimates of Equation (2) using the 3-digit SITC sample of 253 goods imported from 47 countries for the entire period $(1922,1925,1928,1931,1933$, and 1935) and for the periods before and after the Great Depression. The tariff is a weighted average of the ad-valorem rates of all goods included in the category. MFN is the share of items of the relevant SITC category, the same measure for quotas ${ }^{46} \mathrm{We}$ interpret the coefficients to represent the average effects of the various trade policies. Over the entire period, the tariff succeeded in curtailing the decline of Spanish imports. This outcome actually conflates various effects. The assumption underlying Equation (2) is that the elasticity of demand across commodity groups in response to changes in the policy variables is uniform. This may not hold, and we relax this assumption in our robustness checks. A related concern is that because duties were specific, ad valorem rates increased in the 1930s as prices fell, the decline varying across commodity groups.

${ }^{46}$ In another specification, we weight MFNs by the value of goods shipped. The results are similar to those reported in Table 4 but at a higher level of significance. 
That said, conforming to our historical account, the coefficient estimates differ for the subperiods in a meaningful way. Before 1931, a period of increasing trade, tariffs, and exchange rates affected imports negatively (Column (2)). The unconditional MFNs of 1927 and 1928 were ineffectual. In the 1920s, Spain's major trading partners had fixed exchange rates. These countries were prone to apply tariffs to insulate their economies (Eichengreen 1992; Eichengreen and Irwin 2010). The peseta would have depreciated in response, but there were limits to this correction in order to maintain flows of foreign capital. Under these circumstances, Spain applied tariffs as a retaliatory measure. In the early to mid-1930s, after the United Kingdom and subsequently the United States abandoned gold, tariffs became an ineffective tool (Columns (3) and (4)). To be clear, the increase in the ad valorem rate was the result of the period's deflation and not the consequence of active and coherent tariff policy, although duties continued to vary across goods. In Table A1 of the Online Appendix, we provide a breakdown of tariffs by type, good, and sub-period.

The 1930s trade shock transformed the nature and direction of policy. Based on Column (4), devaluation remained a practical instrument increasing trade by around 40 percent. But the Second Republic sought to avoid tariff retaliation and competitive devaluations and turned toward reciprocal agreements. Conditional MFN clauses had a positive effect, their adoption boosting imports on average by 56 percent. This amounted to an ad valorem tariff equivalent of 75 percent. ${ }^{47}$ Put differently, say in 1935, the adoption of MFNs would have entirely offset the average tariff on imports of about 40 percent (calculated from Table A1 of the Online Appendix). We can also approximate the specific contribution of goods with MFN clauses to the growth in imports. For 1935, the figure is 60 percent of imports. ${ }^{48}$

We include in Column (4) our two measures of quotas. The results are striking. As anticipated, stand-alone quotas have a negative sign.

\footnotetext{
${ }^{47}$ Here we follow Glick and Taylor's (2010, pp. 108 and 109, n. 33) procedure of measuring the effect of war on trade. De Bromhead et al. (2019b) propose an alternative method of calculating the impact of the trade treaties for cases in which the MFN and tariff coefficients are both significant. Using their method, we are restricted to France and countries in the sterling bloc. For the former, we estimate a tariff equivalent of 69 percent.

${ }^{48}$ For this calculation, we follow Lampe $(2009$, p. 1032). The contribution to total imports from a MFN treaty or Imports MFN $=\left[\operatorname{Exp}\left(\right.\right.$ coefficient of MFN)-1] imports $_{\mathrm{kj}}$, if MFN $=1$ and year $=1935 ; \mathrm{k}$ goods; $j$ countries. Value of the MFN coefficient $=0.560$ from Column (4), Table 4. Lampe estimates that the contribution of the Cobden-Chevalier MFN network in 1875 to the increase in imports was 32.5 percent. Our figure is larger because the MFN network in the $1930 \mathrm{~s}$ was more extensive than in the mid-nineteenth century and because we estimate the effect of MFN treaties for a single country and Lampe calculates an average for a group of countries.
} 
In contrast, fixing quotas in trade treaties was an effective policy in promoting imports. The expectation was that foreign countries would reciprocate and open markets for Spanish exports. In fact, the inclusion of quotas increases the coefficient of MFN clauses. Finally, Columns (5) and (6) omit the MFN variable. In this setup, we can ask whether or not MFNs are merely capturing changes in the tariff variable. But the coefficients on tariffs in Columns (3) and (5), and (4) and (6) are comparable, the implication being that the adoption of MFNs had an independent influence. They reduced uncertainty in an adverse trade environment.

\section{Robustness Checks}

Our robustness checks take several forms. ${ }^{49}$ In the retreat from globalization in the 1930s, groups of countries emerged with comparable exchange rates and trade policies. Table 5 divides Spain's trading partners into gold and sterling blocs. ${ }^{50} \mathrm{We}$ ask whether or not Spanish trade policy adapted to the different policies of these groups. We answer in the affirmative. Eichengreen and Irwin (2010) claimed that gold bloc countries were more prone to use tariffs. With this group, Spain tended to adopt a combination of tariffs and conditional MFNs. The former acting as a stick to dissuade imports and the latter as a carrot to encourage trade. Contrary to expectations, stand-alone quotas have a positive sign, an indication that quotas were fixed in relation to imports of these countries in previous years. As for the sterling bloc, these countries favored currency adjustments. Spain resorted to tariffs and quotas in treaties in response. With this group, Spain avoided negotiating conditional MFNs since competitive devaluation would weaken the effectiveness of treaties in encouraging exports.

Table 6 reports the effects of policy on imports by sector. ${ }^{51}$ In this setup, the elasticities of the trade policy variables are allowed to vary across commodity groups. Since our sample is heavily weighted to the manufacturing and agricultural sectors, the coefficients and levels of significance in Columns (1)-(4) are comparable to those of the baseline. ${ }^{52}$

\footnotetext{
${ }^{49}$ Online Appendix C reports additional checks.

${ }^{50}$ Gold bloc countries: Belgium, France, the Netherlands, and Switzerland. Sterling bloc countries: Argentina, Australia, the British colonies, Denmark, Egypt, Finland, Japan, New Zealand, Norway, Portugal, Sweden, Thailand, the United Kingdom, and South Africa. The results for individual countries are available upon request.

${ }^{51}$ The relevant 3 -digit codes are agriculture (0-211); manufacturing (511-910); textiles (651658); heavy industry (671-831 and 871-899); and raw materials (211-510).

${ }^{52}$ In 7 of 10 columns, the coefficient for tariffs has a negative sign; the exchange rate is negative in 8 of 10; and MFN is positive in 7 of 10 .
} 
TABLE 5

THE EFFECT OF TRADE POLICY ON IMPORTS: GOLD BLOC AND STERLING BLOC COUNTRIES

\begin{tabular}{|c|c|c|c|c|c|c|}
\hline & (1) & (2) & (3) & (4) & $(5)$ & (6) \\
\hline Dependent Variable: & $\begin{array}{c}\text { Gold } \\
\text { Bloc } \\
\text { Imports }\end{array}$ & $\begin{array}{c}\text { Gold } \\
\text { Bloc } \\
\text { Imports }\end{array}$ & $\begin{array}{c}\text { Gold } \\
\text { Bloc } \\
\text { Imports }\end{array}$ & $\begin{array}{l}\text { Sterling } \\
\text { Bloc } \\
\text { Imports }\end{array}$ & $\begin{array}{l}\text { Sterling } \\
\text { Bloc } \\
\text { Imports }\end{array}$ & $\begin{array}{l}\text { Sterling } \\
\text { Bloc } \\
\text { Imports }\end{array}$ \\
\hline $\begin{array}{l}\text { Method } \\
\text { Period }\end{array}$ & $\begin{array}{c}\text { PPML } \\
1922-1935\end{array}$ & $\begin{array}{c}\text { PPML } \\
1922-1928\end{array}$ & $\begin{array}{c}\text { PPML } \\
1931-1935\end{array}$ & $\begin{array}{c}\text { PPML } \\
1922-1935\end{array}$ & $\begin{array}{c}\text { PPML } \\
1922-1928\end{array}$ & $\begin{array}{c}\text { PPML } \\
1931-1935\end{array}$ \\
\hline $\log$ (GDP exporter) & $\begin{array}{c}1.425 \\
(1.383)\end{array}$ & $\begin{array}{c}4.276 * * * \\
(1.636)\end{array}$ & $\begin{array}{l}-3.255 \\
(1.985)\end{array}$ & $\begin{array}{c}0.907 \\
(0.784)\end{array}$ & $\begin{array}{c}0.744 \\
(1.896)\end{array}$ & $\begin{array}{c}0.128 \\
(0.302)\end{array}$ \\
\hline $\log (1+$ tariff $)$ & $\begin{array}{l}0.0579 \\
(0.436)\end{array}$ & $\begin{array}{c}0.868 \\
(0.640)\end{array}$ & $\begin{array}{c}-2.214 * \\
(1.248)\end{array}$ & $\begin{array}{c}-2.214 * * * \\
(0.509)\end{array}$ & $\begin{array}{c}-2.039 * * * \\
(0.275)\end{array}$ & $\begin{array}{c}-12.54 * * * \\
(2.175)\end{array}$ \\
\hline MFN & $\begin{array}{c}0.659 * * * \\
(0.118)\end{array}$ & $\begin{array}{c}0.657 * * \\
(0.276)\end{array}$ & $\begin{array}{c}0.830 * * * \\
(0.146)\end{array}$ & $\begin{array}{l}-0.115 \\
(0.134)\end{array}$ & $\begin{array}{l}-0.176 \\
(0.174)\end{array}$ & \\
\hline Log (exchange rate) & $\begin{array}{c}0.204 \\
(0.253)\end{array}$ & $\begin{array}{l}-0.244 \\
(0.364)\end{array}$ & $\begin{array}{c}-3.375^{* * *} \\
(0.881)\end{array}$ & $\begin{array}{l}-0.176 \\
(0.474)\end{array}$ & $\begin{array}{l}0.956^{*} \\
(0.580)\end{array}$ & $\begin{array}{c}-0.686 * * \\
(0.319)\end{array}$ \\
\hline Quota & $\begin{array}{c}4.132 * * * \\
(1.390)\end{array}$ & & $\begin{array}{c}3.986 * * * \\
(0.505)\end{array}$ & $\begin{array}{c}-3.599 * * \\
(1.450)\end{array}$ & & $\begin{array}{l}-1.336 \\
(1.673)\end{array}$ \\
\hline Quota in treaty & $\begin{array}{c}-1.134 * * \\
(0.490)\end{array}$ & & $\begin{array}{c}0.365 \\
(0.276)\end{array}$ & $\begin{array}{l}1.822 * * \\
(0.727)\end{array}$ & & $\begin{array}{c}1.537 * * \\
(0.680)\end{array}$ \\
\hline Observations & 4,252 & 2,074 & 2,000 & 6,523 & 2,627 & 2,759 \\
\hline
\end{tabular}

Notes: Dependent variable is the value of imports by good, country, and year. Columns (1), (2), and (3), restricted to imports from the countries belonging to the gold bloc; Columns (4), (5), and (6), imports from countries belonging to the sterling pound bloc. Estimates using poi2hdfe. Regressions control for good*country and good*year fixed effects. Robust standard errors clustered by country in parentheses. *** $\mathrm{p}<0.01, * * \mathrm{p}<0.05, * \mathrm{p}<0.1$

Source: See Online Appendix A.

As before, tariffs impeded imports of agricultural goods, manufacturing and heavy industrial items, and raw materials before 1931, but not after (with the exception of heavy industrial goods). Confirming our previous results, MFN clauses promoted agricultural and manufacturing goods after 1931, whereas a lower exchange rate deterred imports in agriculture, heavy industry, and raw materials. Quotas have a negative sign for agricultural products and are significantly negative for heavy industrial goods (Column (8)). Regarding quotas contained in trade treaties, they have a positive effect on imports of agricultural goods (Column (2)). The majority of Spanish quotas were applied on food items and raw materials, which was also the case for the United Kingdom (de Bromhead et al. 2019a, 2019b). While it is tempting to speculate that Spain was disposed to exchange market access between narrow product groups, for instance, citrus fruits for animal oils and fats so as to manage conflicting 


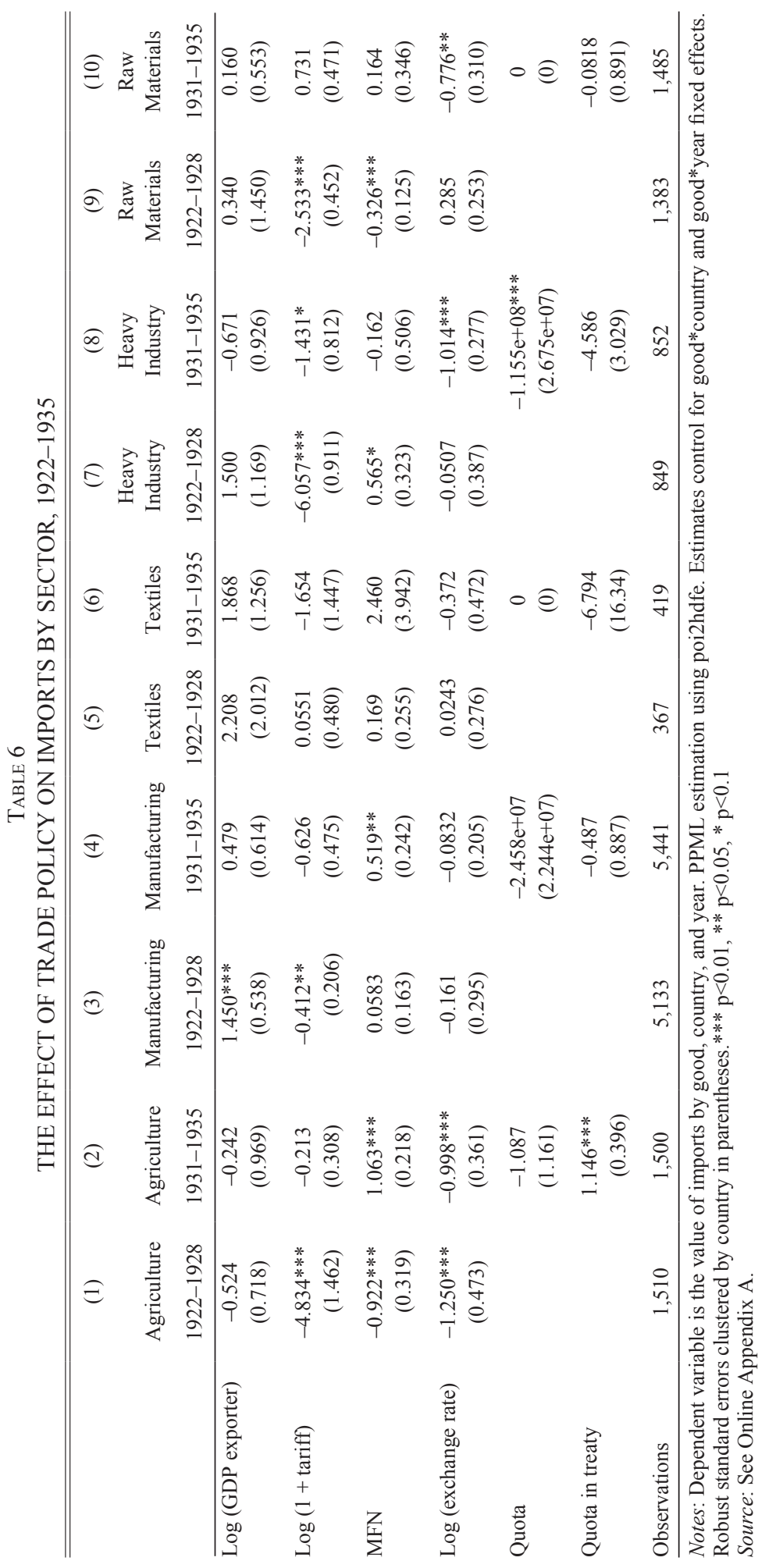


interests within the agrarian lobby, we have not come across evidence of this bargaining strategy in the official treaty reports. More probably, this trading practice arose because Spanish exports were in fact restricted to agricultural goods.

\section{Imports: The Extensive Margin}

In this section, we turn our attention to the effect of trade policy on the extensive margin of changes in imports. To motivate, consider again the number of Spanish imports by source in Figure 6. While the number of products shipped by Germany was stable, France lost more than 100 items between 1925 and 1935, and the United Kingdom about 140 between 1925 and 1933. The United States was an outlier - its export numbers decreased between 1922 and 1931 - and then recovered. By 1935 it had added 100 export items over the period. Adopting the framework of Table 3 , changes of this nature represent movements in continuous goods along the extensive margin.

What was the role of trade policy behind these fluctuations? Did changes in fixed costs affect the number of products shipped to Spain? We estimate the determinants of market entry and exit at the goodcountry level to address these questions. We construct a variable that takes the value of one when the good is imported by Spain in a given year and not in the previous year (or more precisely three years previously). The variable is coded as zero when the good is not imported. We also consider whether or not the good becomes permanent in the Spanish market. This occurs when a good has a positive sign in the current and subsequent years. In this case, the variable takes the value of one in the first year in which the product becomes a permanent import and zero otherwise. Symmetrically, we construct a variable of the decision to exit the Spanish market, which is 1 when a good is not imported in the current year but shipped in previous years. The variable takes the value of zero when imported. Finally, we establish a permanent market exit variable coded as one in the year the good exits permanently and zero otherwise.

We estimate the probability of entry or exit for a good $g$ from country $c$ to Spain in year $t$ of this form:

$$
\begin{aligned}
\Pi_{g c t}=\alpha_{1} \ln \left(Y_{c t}\right) & +\alpha_{2} \ln \left(Y_{\text {Spain }}\right)+\beta \ln \left(x_{c}\right)+\gamma \ln \left(1+t_{g c t}\right)+\delta \ln E_{c t} \\
& +\phi M F N_{g c t}+\gamma Q_{g t}+\mu Q_{g c t}+d_{t}+\ln \left(\eta_{g c t}\right),
\end{aligned}
$$

where $\Pi_{g c t}$ is the probability of entry or exit at the good-country-year level, $Y_{c t}$ is the GDP of country $c$ in year $t ; Y_{\text {Spain } t}$ is the GDP of Spain in 
year $t ; x_{c}$ comprises the time-invariant trade resistance variables, such as distance, border country, language, and colony of another country; the year fixed effect, $d_{t}$; all other variables as in Equations (1) and (2). Applying a pooled logit model, we consider the periods before and after 1931. The dependent variable is measured as the probability that the source country is among the set of countries shipping good $g$ in year $t$ to Spain. The inclusion of time-invariant trade resistant variables and Spanish GDP distinguishes Equation (3) from Equation (2). We expect that MFNs would have increased the probability of entry and reduced that of exit.

Table 7 reports our estimation of the entry of goods. Robust standard errors are clustered at the country-origin or exporter-good level. Regarding market entry, the gravity-model variables have the predicted results. Distance affects negatively and market size (GDP of exporter) positively market entry (Column (1)) and permanent entry (Column (4)). The absolute value of the distance coefficient actually declines in the 1930s, a result in line with Adam's (2019) claim that international transports costs posed a diminishing barrier to trade. In all specifications, the border dummy is negative because France and Portugal reduced exports. The relationship between Spanish GDP and market entry implies that the demand for imports was inelastic. In the 1920s, the growth in GDP prompted the entry of goods, but contracting income after 1931 had the same effect.

The results convey the importance of trade costs in the entry of products. While tariffs did not affect the intensive margin for the period after 1931, they did matter for the extensive margin. Tariffs and devaluation insulated the domestic market from foreign competition, but these policies augmented uncertainty and held back the entry of new goods. In contrast, the adoption of MFNs offset these barriers and fostered both market entry and permanent entry in all periods, excluding permanent entry in 1922-1928. Concretely, between 1931 and 1935, the average marginal (partial) contribution of a MFN on the probability of goods entering the Spanish market was 3.5 percentage points, whereas tariffs and the exchange rate each reduced entry by 0.5 points. Stand-alone quotas did act as a barrier to permanent entry.

In principle, we would anticipate opposite signs on the market exit variables. But the regressions in Table 8 present a more nuanced picture of the contribution of fixed costs to the exit of goods. With the exception of stand-alone quotas and quotas in a trade treaty, the gravity model and policy variables for entry and exit have the same sign and are significant, although the coefficients of the latter are smaller. Tariffs did not cause 
TABLE 7

MARKET ENTRY AND PERMANENT MARKET ENTRY OF IMPORTS (LOGIT REGRESSIONS)

\begin{tabular}{|c|c|c|c|c|c|c|}
\hline & (1) & (2) & (3) & (4) & (5) & (6) \\
\hline Dependent Variable & $\begin{array}{c}\text { Market } \\
\text { Entry }\end{array}$ & $\begin{array}{c}\text { Market } \\
\text { Entry }\end{array}$ & $\begin{array}{c}\text { Market } \\
\text { Entry }\end{array}$ & $\begin{array}{c}\text { Permanent } \\
\text { Market } \\
\text { Entry }\end{array}$ & $\begin{array}{c}\text { Permanent } \\
\text { Market } \\
\text { Entry }\end{array}$ & $\begin{array}{c}\text { Permanent } \\
\text { Market } \\
\text { Entry }\end{array}$ \\
\hline Period & 1922-1935 & $1922-1928$ & $1931-1935$ & $1922-1935$ & $1922-1928$ & 1931-1935 \\
\hline $\log$ (GDP exporter) & $\begin{array}{c}0.006 * * * \\
(0.001)\end{array}$ & $\begin{array}{c}0.006 * * * \\
(0.001)\end{array}$ & $\begin{array}{c}0.006 * * * \\
(0.001)\end{array}$ & $\begin{array}{c}0.004 * * * \\
(0.001)\end{array}$ & $\begin{array}{c}0.002 * * * \\
(0.001)\end{array}$ & $\begin{array}{c}0.005 * * * \\
(0.001)\end{array}$ \\
\hline log (GDP Spain) & $\begin{array}{c}-0.064 * * \\
(0.020)\end{array}$ & $\begin{array}{c}0.057 * * \\
(0.029)\end{array}$ & $\begin{array}{c}-0.045^{* * *} \\
(0.008)\end{array}$ & $\begin{array}{c}-0.118 * * * \\
(0.012)\end{array}$ & $\begin{array}{l}0.0004 \\
(0.014)\end{array}$ & $\begin{array}{c}-0.102 * * * \\
(0.008)\end{array}$ \\
\hline $\log ($ distance $)$ & $\begin{array}{c}-0.011 * * * \\
(0.002)\end{array}$ & $\begin{array}{c}-0.013^{* * *} \\
(0.002)\end{array}$ & $\begin{array}{c}-0.009 * * * \\
(0.002)\end{array}$ & $\begin{array}{c}-0.006^{* * *} \\
(0.001)\end{array}$ & $\begin{array}{c}-0.005 * * * \\
(0.001)\end{array}$ & $\begin{array}{c}-0.006 * * * \\
(0.001)\end{array}$ \\
\hline Border & $\begin{array}{c}-0.021 * * * \\
(0.005)\end{array}$ & $\begin{array}{c}-0.022 * \\
(0.008)\end{array}$ & $\begin{array}{c}-0.014 * * \\
(0.006)\end{array}$ & $\begin{array}{c}-0.016 * * * \\
(0.004)\end{array}$ & $\begin{array}{c}-0.012 * * \\
(0.005)\end{array}$ & $\begin{array}{c}-0.016 * * * \\
(0.005)\end{array}$ \\
\hline Common language & $\begin{array}{l}-0.006 \\
(0.007)\end{array}$ & $\begin{array}{c}0.004 \\
(0.010)\end{array}$ & $\begin{array}{l}-0.011 \\
(0.008)\end{array}$ & $\begin{array}{c}-0.007 * \\
(0.004)\end{array}$ & $\begin{array}{l}-0.005 \\
(0.005)\end{array}$ & $\begin{array}{l}-0.008 \\
(0.006)\end{array}$ \\
\hline Colony & $\begin{array}{l}-0.005 \\
(0.006)\end{array}$ & $\begin{array}{l}-0.008 \\
(0.009)\end{array}$ & $\begin{array}{l}-0.001 \\
(0.007)\end{array}$ & $\begin{array}{l}-0.002 \\
(0.003)\end{array}$ & $\begin{array}{l}0.0004 \\
(0.004)\end{array}$ & $\begin{array}{l}-0.002 \\
(0.005)\end{array}$ \\
\hline $\log (1+$ tariff $)$ & $\begin{array}{c}-0.005^{* * *} \\
(0.001)\end{array}$ & $\begin{array}{c}-0.004 * \\
(0.001)\end{array}$ & $\begin{array}{c}-0.005 * * * \\
(0.001)\end{array}$ & $\begin{array}{c}-0.003 * * * \\
(0.001)\end{array}$ & $\begin{array}{l}-0.001 \\
(0.001)\end{array}$ & $\begin{array}{c}-0.004 * * * \\
(0.001)\end{array}$ \\
\hline MFN & $\begin{array}{c}0.024 * * * \\
(0.002)\end{array}$ & $\begin{array}{c}0.010 * * \\
(0.004)\end{array}$ & $\begin{array}{c}0.035 * * * \\
(0.003)\end{array}$ & $\begin{array}{c}0.015 * * * \\
(0.002)\end{array}$ & $\begin{array}{c}-0.0001 \\
(0.002)\end{array}$ & $\begin{array}{c}0.028 * * * \\
(0.003)\end{array}$ \\
\hline Log (exchange rate) & $\begin{array}{c}-0.004 * * * \\
(0.001)\end{array}$ & $\begin{array}{c}-0.003 * * * \\
(0.001)\end{array}$ & $\begin{array}{c}-0.005 * * * \\
(0.001)\end{array}$ & $\begin{array}{c}-0.002 * * * \\
(0.0004)\end{array}$ & $\begin{array}{l}-0.001 * \\
(0.0004)\end{array}$ & $\begin{array}{c}-0.003 * * * \\
(0.001)\end{array}$ \\
\hline Quota & $\begin{array}{l}-0.014 \\
(0.009)\end{array}$ & & $\begin{array}{l}-0.014 \\
(0.009)\end{array}$ & $\begin{array}{c}-0.010 * \\
(0.005)\end{array}$ & & $\begin{array}{c}-0.013 * \\
(0.007)\end{array}$ \\
\hline Quota in treaty & $\begin{array}{l}-0.118 \\
(0.093)\end{array}$ & & $\begin{array}{l}-0.112 \\
(0.091)\end{array}$ & $\begin{array}{l}-0.057 \\
(0.047)\end{array}$ & & $\begin{array}{l}-0.074 \\
(0.063)\end{array}$ \\
\hline Year dummies & Yes & Yes & Yes & Yes & Yes & Yes \\
\hline Observations & 46,314 & 18,624 & 27,690 & 46,314 & 18,624 & 27,690 \\
\hline
\end{tabular}

Notes: Dependent variables are market entry and permanent market entry. See text for definitions. The table reports average marginal (partial) effects. Robust standard errors clustered at good and exporter country level are in parentheses. Method of estimation is logit maximum likelihood. $* * * \mathrm{p}<0.01, * * \mathrm{p}<0.05, * \mathrm{p}<0.1$ Source: See Online Appendix A.

permanent exit. We speculate that firms having previously assumed beachhead or fixed costs of entry were not inclined to leave the market. As the exchange rate depreciated, however, exit was more likely, perhaps because foreign firms would have taken devaluation as a signal of future financial uncertainty. As for MFNs, they boosted the probability of exit since agreements did not cover all goods. Similarly, stand-alone quotas 
TABLE 8

MARKET EXIT AND PERMANENT MARKET EXIT OF IMPORTS (LOGIT REGRESSIONS)

\begin{tabular}{|c|c|c|c|c|c|c|}
\hline \multirow[b]{2}{*}{ Dependent Variable } & (1) & (2) & (3) & (4) & (5) & (6) \\
\hline & $\begin{array}{l}\text { Market } \\
\text { Exit }\end{array}$ & $\begin{array}{l}\text { Market } \\
\text { Exit }\end{array}$ & $\begin{array}{c}\text { Market } \\
\text { Exit }\end{array}$ & $\begin{array}{l}\text { Permanent } \\
\text { Market } \\
\text { Exit }\end{array}$ & $\begin{array}{c}\text { Permanent } \\
\text { Market } \\
\text { Exit }\end{array}$ & $\begin{array}{c}\text { Permanent } \\
\text { Market } \\
\text { Exit }\end{array}$ \\
\hline Period & $1922-1935$ & $1922-1928$ & 1931-1935 & $1922-1935$ & $1922-1928$ & $1931-1935$ \\
\hline $\log$ (GDP exporter) & $\begin{array}{c}0.005 * * * \\
(0.001)\end{array}$ & $\begin{array}{c}0.004 * * * \\
(0.001)\end{array}$ & $\begin{array}{c}0.005 * * * \\
(0.001)\end{array}$ & $\begin{array}{c}0.002 * * \\
(0.001)\end{array}$ & $\begin{array}{l}0.0002 \\
(0.001)\end{array}$ & $\begin{array}{c}0.003 * * * \\
(0.001)\end{array}$ \\
\hline log (GDP Spain) & $\begin{array}{l}0.035 * \\
(0.019)\end{array}$ & $\begin{array}{c}-0.062 * * \\
(0.026)\end{array}$ & $\begin{array}{c}0.027 * * * \\
(0.007)\end{array}$ & $\begin{array}{c}-0.044 * * * \\
(0.012)\end{array}$ & $\begin{array}{c}-0.052 * * \\
(0.017)\end{array}$ & $\begin{array}{c}-0.028 * * * \\
(0.006)\end{array}$ \\
\hline $\log$ (distance) & $\begin{array}{c}-0.015 * * * \\
(0.002)\end{array}$ & $\begin{array}{c}-0.015^{* * *} \\
(0.003)\end{array}$ & $\begin{array}{c}-0.014 * * * \\
(0.002)\end{array}$ & $\begin{array}{c}-0.005^{* * *} \\
(0.001)\end{array}$ & $\begin{array}{l}-0.002 \\
(0.002)\end{array}$ & $\begin{array}{c}-0.007 * * * \\
(0.002)\end{array}$ \\
\hline Border & $\begin{array}{l}-0.003 \\
(0.004)\end{array}$ & $\begin{array}{c}-0.013 * * \\
(0.007)\end{array}$ & $\begin{array}{c}0.005 \\
(0.004)\end{array}$ & $\begin{array}{c}0.006 * * \\
(0.003)\end{array}$ & $\begin{array}{l}-0.002 \\
(0.005)\end{array}$ & $\begin{array}{c}0.010 * * \\
(0.003)\end{array}$ \\
\hline Common language & $\begin{array}{l}0.0004 \\
(0.006)\end{array}$ & $\begin{array}{c}0.004 \\
(0.009)\end{array}$ & $\begin{array}{l}-0.002 \\
(0.007)\end{array}$ & $\begin{array}{l}0.0004 \\
(0.004)\end{array}$ & $\begin{array}{c}0.002 \\
(0.006)\end{array}$ & $\begin{array}{l}-0.002 \\
(0.006)\end{array}$ \\
\hline Colony & $\begin{array}{l}0.009 * \\
(0.005)\end{array}$ & $\begin{array}{c}0.010 \\
(0.007)\end{array}$ & $\begin{array}{c}0.009 \\
(0.006)\end{array}$ & $\begin{array}{c}0.004 \\
(0.004)\end{array}$ & $\begin{array}{c}0.003 \\
(0.005)\end{array}$ & $\begin{array}{c}0.004 \\
(0.005)\end{array}$ \\
\hline $\log (1+$ tariff $)$ & $\begin{array}{c}-0.003 * * \\
(0.001)\end{array}$ & $\begin{array}{c}-0.005^{* * *} \\
(0.001)\end{array}$ & $\begin{array}{l}-0.001 \\
(0.001)\end{array}$ & $\begin{array}{l}-0.001 \\
(0.001)\end{array}$ & $\begin{array}{l}0.0001 \\
(0.001)\end{array}$ & $\begin{array}{l}-0.001 \\
(0.001)\end{array}$ \\
\hline MFN & $\begin{array}{c}0.017 * * * \\
(0.002)\end{array}$ & $\begin{array}{c}0.014 * * * \\
(0.004)\end{array}$ & $\begin{array}{c}0.019 * * * \\
(0.003)\end{array}$ & $\begin{array}{c}0.009 * * * \\
(0.002)\end{array}$ & $\begin{array}{c}0.007 * * \\
(0.003)\end{array}$ & $\begin{array}{c}0.009 * * * \\
(0.002)\end{array}$ \\
\hline Log (exchange rate) & $\begin{array}{c}-0.004 * * * \\
(0.001)\end{array}$ & $\begin{array}{c}-0.004 * * * \\
(0.001)\end{array}$ & $\begin{array}{c}-0.004 * * * \\
(0.001)\end{array}$ & $\begin{array}{c}-0.002 * * * \\
(0.0003)\end{array}$ & $\begin{array}{r}-0.001 * * \\
(0.001)\end{array}$ & $\begin{array}{c}-0.003 * * * \\
(0.001)\end{array}$ \\
\hline Quota & $\begin{array}{c}0.018 * * \\
(0.007)\end{array}$ & & $\begin{array}{c}0.018 * * \\
(0.006)\end{array}$ & $\begin{array}{l}0.012 * * \\
(0.004)\end{array}$ & & $\begin{array}{c}0.014 * * \\
(0.004)\end{array}$ \\
\hline Quota in treaty & $\begin{array}{c}0.015 \\
(0.038)\end{array}$ & & $\begin{array}{c}0.012 \\
(0.037)\end{array}$ & $\begin{array}{c}0.007 \\
(0.022)\end{array}$ & & $\begin{array}{c}0.005 \\
(0.025)\end{array}$ \\
\hline $\begin{array}{l}\text { Year dummies } \\
\text { Observations }\end{array}$ & $\begin{array}{c}\text { Yes } \\
46,314\end{array}$ & $\begin{array}{c}\text { Yes } \\
18,624\end{array}$ & $\begin{array}{c}\text { Yes } \\
27,690\end{array}$ & $\begin{array}{c}\text { Yes } \\
46,314\end{array}$ & $\begin{array}{c}\text { Yes } \\
18,624\end{array}$ & $\begin{array}{c}\text { Yes } \\
27,690\end{array}$ \\
\hline
\end{tabular}

Notes: Dependent variables are market exit and permanent market exit. See text for definitions. The table reports average marginal (partial) effects. Robust standard errors clustered at good and exporter country level are in parentheses. Method of estimation is logit maximum likelihood. $* * * \mathrm{p}<0.01,{ }^{* *} \mathrm{p}<0.05,{ }^{*} \mathrm{p}<0.1$

Source: See Online Appendix A.

chased out goods. The bottom line is that when fixed costs rose, so did the exit of goods.

\section{Exports: Spain's Quandary}

Did the strategy of exchanging market access succeed? Figures 6 and 7 described the co-movement of the number of products imported and exported. In this section, we ask whether trade policy encouraged this 
pattern. Several concerns hamper our evaluation. To begin, we have partial information on trade policies of export destinations, like tariffs, because the details are available in foreign sources only. We are therefore limited to the export products listed in MFN agreements, although some treaties, for instance, that with Germany and Italy, gave only the reference numbers recorded in their respective tariff legislation. The lack of diversity in Spanish exports and the fact that we are restricted to evidence for two years and ten countries hinder our analysis as well.

Given these considerations, we adopt a bare-bones regression of the form:

$$
\text { Exports }_{g c t}=\alpha \ln \left(Y_{c t}\right)+\beta \ln \left(x_{c}\right)+\delta \ln E_{c t}+\phi \text { Treaty }_{c t}+d_{g c}+\ln \left(\eta_{g c t}\right),
$$

where Exports $s_{g c t}$ is the share of exports of each good $g$ from Spain to country $c$ in year $t$; Treaty is a dummy variable which takes the value of 1 if a country $c$ signed a trade treaty in period $t$ and 0 otherwise; all other variables as in Equations (2) and (3). ${ }^{53} \mathrm{We}$ are interested in the coefficient for Treaty. A positive coefficient in the period beginning in 1931 would indicate that the Second Republic's initiative improved exposure of Spanish goods abroad, although this does not imply outright policy success.

In Table 9, we present the effects of various trade measures on exports for 1925-1928 and 1931-1935. As with imports, we apply PPML estimation because of heteroskedasticity in the trade data and the presence of zero exports for some year, country, and good combinations of bilateral trade. In fact, the zeroes in export trade are more prevalent than in the case of imports. The first two columns indicate that the Second Republic's policy was advantageous. In 1928, a lower exchange rate favored exports, but trade treaties failed to improve Spain's prospects. In 1935, exports increased with the GDP of the destination country and a lower peseta. For that year, the treaty variable is positive and significant, giving comfort to our claim on the role of conditional MFNs as a lever to expand market access for Spanish goods. The last two columns present a check on our findings. With OLS, the results are as expected imprecise, but the coefficients for 1935 have the anticipated signs. The treaty coefficient is significant at the 0.12 level. Applying the same procedure used for imports, we estimate that in 1935 the contribution of MFN treaties to the increase in total exports was in the order of 36 percent. The corresponding figure was

\footnotetext{
${ }^{53}$ A difference-in-difference framework poses problems since there was an overlap in the type of MFNs negotiated across the two years. Several conditional MFNs signed prior to 1928 were still operational (see Table 1) after this date. Treaty refers to all types of bilateral accords negotiated.
} 
TABLE 9

THE EFFECT OF TRADE POLICY ON EXPORTS, 1928 AND 1935

\begin{tabular}{lcccc}
\hline \hline & $(1)$ & $(2)$ & $(3)$ & $(4)$ \\
Method & PPML & PPML & OLS & OLS \\
Year & 1928 & 1935 & 1928 & 1935 \\
\hline Treaty & -0.205 & $0.553^{*}$ & -0.001 & 0.012 \\
& $(0.398)$ & $(0.286)$ & $(0.015)$ & $(0.007)$ \\
Log (GDP importer) & 0.060 & $0.349^{* * *}$ & 0.004 & $0.009^{* *}$ \\
& $(0.184)$ & $(0.127)$ & $(0.007)$ & $(0.003)$ \\
Log (exchange rate) & $0.345^{* * *}$ & $0.140^{*}$ & $0.011^{*}$ & 0.004 \\
& $(0.126)$ & $(0.084)$ & $(0.005)$ & $(0.003)$ \\
Constant & $-4.081^{*}$ & $-7.545^{* * *}$ & -0.006 & $-0.062^{*}$ \\
& $(2.173)$ & $(1.615)$ & $(0.077)$ & $(0.033)$ \\
Observations & & & & \\
R-squared & 2,580 & 2,580 & 2,580 & 2,580 \\
\hline
\end{tabular}

Notes: Dependent variable is the share of exports by good and country for 1928 and 1935 for the top 10 leading export destinations of Spain (Argentina, Belgium, France, Germany, Italy, the Netherlands, Sweden, Switzerland, United Kingdom, and the United States). Treaty is a dummy variable, which is 1 if a country signed a trade treaty with Spain during the periods 1925-1928 and 1931-1935. All regressions control for good*country fixed effects. Estimates using PPML and OLS. Robust standard errors clustered by country in parentheses. ${ }^{* * *} \mathrm{p}<0.01,{ }^{* *} \mathrm{p}<0.05,{ }^{*} \mathrm{p}<0.1$ Source: See Online Appendix A.

11 percent for France, 12 percent for Germany, and 3 percent for Italy. ${ }^{54}$ All told, the treaties had a larger effect on imports than exports ( 60 versus 36 percent).

It is necessary to put these findings in perspective. The Second Republic's dual challenge of meeting domestic demands and accessing export markets during the international crisis of the 1930s was formidable. Our analysis suggests that reciprocal agreements had the anticipated effect on imports but that Spain confronted significant barriers on the export side, the result of a dependence on a handful of agricultural exports destined to a narrow group of markets. The absence of empire or membership in a trading bloc compelled Spain to negotiate separate agreements with trading partners entangled in their own domestic politics. Spain, like other small countries, simply did not have the capacity, resources, or bargaining heft to negotiate effectively on a case-by-case

\footnotetext{
${ }^{54} \mathrm{We}$ are restricted in our calculation of the effects of MFNs on exports because we have information on the presence of a treaty with a trading partner but not of the goods contained in these treaties. We adapt Lampe's approach (2009, p. 1033). The contribution to total exports from a MFN or Exports $_{\mathrm{MFN}}=\left[\operatorname{Exp}\left(\right.\right.$ coefficient of MFN treaty)-1] exports $_{\mathrm{kj}}$, if treaty $=1$ and year $=$ $1935 ; \mathrm{k}=253$ goods; $j=10$ countries. Value of the MFN coefficient $=0.553$ from Column (2), Table 9. Our procedure for estimating total exports by country is the same.
} 
basis. Under these circumstances, policymakers had little margin of error. The best the new Republic could achieve was to set the groundwork for a future rebound in global economic activity — an opportunity that never came about.

\section{CONCLUDING REMARKS ON THE GREAT DEPRESSION IN SPAIN: A PATH NOT TAKEN?}

In this paper, we have compiled a new granular dataset on Spanish exports and imports and good-country information on MFNs, tariffs, and quotas. We reject the view that Spain was insulated from the economic shocks of the interwar period. Flexible exchange rates and discriminatory practices were an inadequate firewall against the global economic crisis. In these circumstances, an active trade policy was more than ever indispensable. We align developments in policy with the contribution of the extensive margin to changes in the value of trade. All told, although the size of the intensive margin was large, that of the extensive margin was not trivial.

The challenge for Spanish authorities was to reconcile external pressures and domestic concerns. In the 1920s, the established sectors of activity had the upper hand, and the state rewarded them with tariff protection. Beginning in 1927, the country negotiated unconditional MFN agreements to encourage exports, but these proved to be ineffective. The advent of the Second Republic was the defining moment in interwar trade policy. New interest groups and new ideas emerged. After 1931 tariff policy was downgraded. In its place, the state negotiated conditional MFN treaties that conceded on a bilateral basis domestic market access of a restricted set of goods in exchange for greater exposure of specific Spanish items abroad. To be sure, the policy was in principle a second-best solution, although perhaps a practical step in managing uncertainty and restoring the multilateral trading network in the long term. The gambit did not achieve fully its intended results, however. The contribution of MFN treaties to the increase in imports was greater than that for exports. This unfavorable outcome was apparently not the result of the shambolic application of a poor policy design but ultimately a consequence of Spain's historical dependence on a narrow range of export products and markets.

Our approach and findings contribute to several areas of interest in international and Spanish economic history of the interwar period: the role of trade policy during the Depression, the latitude of small economies in responding to economic shocks, and the clash of domestic goals and 
external constraints during the Second Republic. We have raised several concerns with the claim that the collapse in income was the handmaiden of the 1930s trade contraction. Aggregate trade data tend to conflate the effects of income and policy. Our good-country level data for Spain identifies an active role for the latter.

On this score, the contrast with the United Kingdom is telling. According to de Bromhead et al. (2019a, 2019b), Britain's adoption of discriminatory trade practices promoted the shift toward imports of Empire goods in the 1930s. Spain, however, was cut off from formal and informal trading blocs. With few options to safeguard markets for exports and in the face of escalating "beggar thy neighbor" trade practices, the Second Republic took the bold and exceptional step of eschewing retaliatory and adversarial measures. In piecemeal fashion, the new government sought out trading partners willing to accept Spanish goods in exchange for market access.

In the last poignant chapter, the Second Republic was hard pressed to establish commercial relationships along these lines, an outcome that may be attributed as much to the geopolitics of the period as to the regime's domestic failures. The eminent historian of interwar Spain Helen Graham (2005) has observed that, well before the Civil War, France was indecisive and the United Kingdom indifferent to the fate of Europe's new democracy. Both countries preferred to deepen ties with their colonies or foreign offshoots, even as Nazi Germany and Fascist. Italy improved their shares of Spanish trade. The Republic's economic fortunes were sealed.

\section{REFERENCES}

Adam, Marc Christopher. "Return of the Tariffs: The Interwar Trade Collapse Revisited." Working Paper No. 8, School of Business and Economics, Freie Universität Berlin, Berlin, Germany, 2019.

Anderson, James E., and Eric van Wincoop, E. "Gravity with Gravitas: A Solution to the Border Puzzle." American Economics Review 93, no. 1 (2003): 170-92.

Ayuda, María-Isabel, and Vicente Pinilla. "Agricultural Exports and Economic Development in Spain during the First Wave of Globalization." Sociedad de Estudios de Historia Agraria - Documentos de Trabajo, DT-SEHA, No. 2001, Universidad de Zaragoza e Instituto Agroalimentario de Aragón, Zaragoza, Spain, 2020.

Azaña, Manuel. Memorias politicas y de Guerra, vols. 1 and 2. Madrid: Rio Saja, 1976.

Causas de la Guerra de España. Barcelona: Crítica, 1986.

Bernard, Andrew B., J. Bradford Jensen, Stephen J. Redding, and Peter K. Schott. "The Margins of U.S. Trade.” American Economic Review 99, no. 2 (2009): 487-93. 
Betrán, Concepción. "1936. Frustrated Hopes: The Great Depression, the Second Republic and the Civil War." In Historical Turning Points in Spanish Economic Growth and Development, 1808-2008, edited by Concepción Betrán and María A. Pons, 89-122. Cham, Switzerland: Palgrave, 2020.

Betrán, Concepción, and Michael Huberman. "International Competition in the First Wave of Globalization: New Evidence on the Margins of Trade." Economic History Review 69, no. 1 (2016): 258-87.

_. "Against the Grain: Spanish Trade Policy in the Interwar Years." Ann Arbor, MI: Inter-university Consortium for Political and Social Research [distributor], 2021-04-01. https://doi.org/10.3886/E136461V2.

Betrán, Concepción, Pablo Martín-Aceña, and María A. Pons. "Financial Crises in Spain: Lessons from the Last 150 Years." Revista de Historia Económica / Journal of Iberian and Latin American Economic History 30, no. 3 (2012): 417 46.

Carreras, Albert, and Xavier Tafunell. Historia económica de la España contemporánea. Barcelona: Crítica, 2004.

Casanova, Julián. The Spanish Republic and Civil War. New York: Cambridge University Press, 2010.

Chaney, Thomas. "Distorted Gravity: The Intensive and Extensive Margins to International Trade." American Economic Review 98, no. 4 (2008): 1077-21.

Comín, Francisco. "El periodo de entreguerras (1919-1935)." In Historia Económica de España. Siglos $X-X X$, edited by Francisco Comín, Enrique Llopis, and Mauro Hernández, 285-329. Barcelona: Crítica, 2002.

Crucini, Mario J. "Sources of Variation in Real Tariff Rates: The United States, 19001940." American Economic Review 84, no. 3 (1994): 732-43.

Crucini, Mario J., and James Kahn. "Tariffs and Aggregate Economic Activity: Lessons from the Great Depression." Journal of Monetary Economics 38, no. 3 (1996): 427-67.

Debaere, Peter, and Shalah Mostashari. "Do Tariffs Matter for the Extensive Margin of International Trade? An Empirical Analysis." Journal of International Economics 81, no. 2 (2010): 163-69.

de Bromhead, Alan, Alan Fernihough, Markus Lampe, and Kevin Hjortshøj O’Rourke. "The Anatomy of a Trade Collapse: The U.K., 1929-1933." European Review of Economic History 23, no. 1 (2019a): 123-44.

- "When Britain Turned Inward: The Impact of Interwar British Protection." American Economic Review 109, no. 2 (2019b): 325-52.

Dutt, Pushan, Ilian Mihov, and Timothy Van Zandt. "The Effect of WTO on the Extensive and the Intensive Margins of Trade." Journal of International Economics 91, no. 2 (2013): 204-19.

Eaton, Jonathan, Marcela Eslava, Maurice Kugler, and James Tybout. "Export Dynamics in Colombia: Firm-level Evidence.” NBER Working Paper No. 13531, Cambridge, MA, October 2007.

Eichengreen, Barry. Golden Fetters: The Gold Standard and the Great Depression, 1919-1939. New York: Oxford University Press, 1992.

Eichengreen, Barry, and Douglas A. Irwin. "The Slide to Protectionism in the Great Depression: Who Succumbed and Why?" Journal of Economic History 70, no. 1 (2010): 87-96.

El Financiero, 1931-1936, various issues. 
Fernández, Eva, and Vicente Pinilla. "Spain." In Wine Globalization: A New Comparative History, edited by Kym Anderson and Vicente Pinilla, 208-37. New York: Cambridge University Press, 2018.

Fouquin, Michel, and Jules Hugot. "Two Centuries of Bilateral Trade and Gravity Data 1827-2014.” CEPII Working Paper No. 14, Paris, France, May 2016.

Garrido, Samuel. "Oranges or "Lemons"? Family Farming and Product Quality in the Spanish Orange Industry, 1870-1960.” Agricultural History 84, no. 2 (2010): 224-43.

Glick, Reuven, and Alan Taylor. "Collateral Damage: Trade Disruption and the Economic Impact of War." Review of Economics and Statistics 92, no. 1 (2010): $102-27$.

Graham, Helen. The Spanish Civil War: A Very Short Introduction. New York: Oxford University Press, 2005.

Guimaraes, Paulo, and Pedro Portugal. "A Simple Feasible Alternative Procedure to Estimate Models with High-dimensional Fixed Effects." Stata Journal 10, no. 4 (2010): 628-49.

Harberler, Gottfried. Quantitative Trade Controls: Their Causes and Nature. Geneva: League of Nations, 1943.

Huberman, Michael, Christopher M. Meissner, and Kim Oosterlinck. "Technology and Geography in the Second Industrial Revolution: New Evidence from the Margins of Trade." Journal of Economic History 77, no. 1 (2017): 39-89.

Irwin, Douglas A. "Multilateral and Bilateral Trade Policies in the World Trading System: An Historical Perspective." In New Dimensions in Regional Integration, edited by Jaime de Melo and Arvind Panagariya, 90-119. Cambridge: Cambridge University Press, 1993.

- Trade Policy Disaster: Lessons from the 1930s. Cambridge, MA: MIT Press, 2012.

- Clashing over Commerce: A History of US Trade Policy. Chicago: University of Chicago Press, 2017.

Irwin, William J. The 1933 Cortes Elections: Origin of the Bienio Negro. New York: Garland, 1991.

Jacks, David S., and Dennis Novy. "Trade Blocs and Trade Wars during the Interwar Period." Asian Economic Policy Review 15, no. 1 (2020): 119-36.

Jackson, Gabriel. The Spanish Republic and the Civil War, 1931-1939. Princeton, NJ: Princeton University Press, 1965.

Jones, Joseph M. Tariff Retaliation: Repercussions of the Hawley-Smoot Bill. Philadelphia, PA: University of Pennsylvania Press, 1934.

Jorge-Sotelo, Enrique. "The Limits to Lender of Last Resort Interventions in Emerging Economies: Evidence from the Gold Standard and the Great Depression in Spain." European Review of Economic History 24, no. 1 (2019): 98-133.

Klasing, Mariko J., and Petros Milionis. "Quantifying the Evolution of World Trade, 1870-1949." Journal of International Economics 92, no. 1 (2014): 185-97.

Lampe, Markus. "Effects of Bilateralism and the MFN Clause on International Trade: Evidence for the Cobden-Chevalier Network, 1860-1875." Journal of Economic History 69, no. 4 (2009): 1012-49.

League of Nations. Commercial Policy in the Interwar Period: International Proposals and National Policies. Geneva: League of Nations, 1942. 
Leitão Diogo, Jaime Pereira, João Pereira Santos, and José Tavares. “The War Next Door or the Reds Are Coming: The Spanish Civil War and the Portuguese Stock Market." Paper presentd to the $7^{\circ}$ Workshop de História Econômica / 7th Brazilian Economic History Workshop, São Paulo, Brazil, August 2019.

Levchenko, Andrei A., Logan T. Lewis, and Linda L. Tesar. "The Collapse of International Trade during the 2008-09 Crisis: In Search of the Smoking Gun." IMF Economic Review 58, no. 2 (2010): 214-53.

Maddison Project Database, version 2018. Bolt, Jutta, Robert Inklaar, Herman de Jong, and Jan Luiten van Zanden. "Rebasing 'Maddison': New Income Comparisons and the Shape of Long-Run Development." GDC Research Memorandum, vol. GD-174, Groningen Growth and Development Center, Groningen, Netherlands, 2018.

Madsen, Jakob B. "Trade Barriers and the Collapse of World Trade during the Great Depression." Southern Economic Journal 67, no. 4 (2001): 848-68.

Malefakis, Edward E. Agrarian Reform and Peasant Revolution in Spain: Origins of the Civil War. New Haven, CT: Yale University Press, 1970.

Martín-Aceña, Pablo, Elena Martínez, and Pilar Nogués. "Floating Against the Tide: Spanish Monetary Policy, 1870-1931.” Universidad Carlos III de Madrid, Working Papers in Economic History, No. 10, Madrid, Spain, September 2011.

Meissner, Christopher M., and John Tang. "Upstart Industrialization and Exports: Evidence from Japan, 1880-1910." Journal of Economic History 78, no. 4 (2018): 1068-102.

Mukand, Sharun, and Dani Rodrik. "The Political Economy of Ideas: On Ideas Versus Interests in Policymaking." NBER Working Paper No. 24467, Cambridge, MA, March 2018.

Palafox, Jordi. “Agricultura d'especulació i crisi econòmica. El País Valenciano durant els anys trenta (1930-1936)." Estudis d'història agraria, no. 3 (1979): 136-62. - "Estructura de la exportación y distribución de beneficios. La naranja en el País Valenciano (1920-1930)." Revista de Historia Económica 1, no. 2 (1983): 339-51.

—. "España y la crisis internacional de 1929: el papel de los desequilibrios internos." In Pasado y Presente: De la Gran Depresión del siglo XX a la Gran Recesión del siglo XXI, edited by Pablo Martín-Aceña, 79-112. Bilbao: Fundación BBVA, 2011.

Payne, Stanley G. Spain's First Democracy: The Second Republic, 1931-1936. Maddison: University of Wisconsin Press, 1993.

Pinilla, Vicente, and María-Isabel Ayuda. "The Political Economy of the Wine Trade: Spanish Exports and the International Market, 1890-1935." European Review of Economic History 6, no. 1 (2002): 51-86.

_. "Taking Advantage of Globalization? Spain and the Building of the International Market in Mediterranean Horticultural Products, 1850-1935." European Review of Economic History 14, no. 2 (2010): 239-74.

Prados de la Escosura, Leandro. Spanish Economic Growth, 1850-2015. London: Palgrave Macmillan, 2017.

Prados de la Escosura, Leandro, and Joan R. Rosés. "The Sources of Long-run Growth in Spain." Journal of Economic History 69, no. 4 (2009): 1063-91.

Prados de la Escosura, Leandro, and Blanca Sánchez-Alonso."Economic Development in Spain, 1815-2017.” EHES Working Paper No. 163, Madrid, Spain, July 2019. 


\section{Spanish Trade Policy in the Interwar Years}

Preston, Paul. The Coming of the Spanish Civil War Reform, Reaction and Revolution in the Second Republic. $2^{\text {nd }}$ edition. London: Routledge, 1994.

Putnam, Robert. "Diplomacy and Domestic Politics: The Logic of Two-level Games." International Organization 42, no. 3 (1988): 427-60.

Ramón-Muñoz, Ramón. "Specialization in the International Market for Olive Oil before World War II." In The Mediterranean Response to Globalization Before 1950, edited by Sevket Pamuk and Jeffrey G. Williamson, 159-98. London: Routledge, 2000.

Revista Nacional de Economía. 1931-1936, various issues.

Richmond, Douglas W. "The Politics of Spanish Financial and Economic Policies during the Second Republic, 1931-1933." The Historian 49, no. 3 (1987): 348 67.

Santos Silva, João M. C., and Silvana Tenreyro. "The Log of Gravity." Review of Economics and Statistics 88, no. 4 (2006): 641-58.

- "Currency Unions in Prospect and Retrospect." Annual Review of Economics 2, no. 1 (2010): 51-74.

Saz Campo, Ismael. "La política exterior de la Segunda República en el primer bienio (1931-1933): Una valoración." Revista de Estudios Internacionales 6, no. 4 (1985): 843-58.

Schott, Peter K. "US Trade Margins during the 2008 Crisis." In The Great Trade Collapse: Causes, Consequences, and Prospects, edited by Richard Baldwin, 127-42. Vox.EU.org Report. Geneva, Switzerland: The Graduate Institute of Geneva, 2009.

Serrano Sanz, José María. "La política comercial ante la crisis del 29. El primer bienio republicano." In La segunda república española. El primer bienio, edited by José Luis García Delgado, 135-51. Madrid: Siglo XXI, 1987.

Simpson, James. Spanish Agriculture: The Long Siesta, 1765-1965. New York: Cambridge University Press, 1996.

Simpson, James, and Juan Carmona. Why Democarcy Failed: The Agrarian Origins of the Spanish Civil War. New York: Cambridge University Press, 2020.

Smith, Tyler. "Does Trade Policy Really Matter?” https://www.aeaweb.org/research/ british-interwar-protectionism-imperial-imports, 25 February 2019.

Spain. Consejo de Economía Nacional. Aranceles de aduanas para la península e islas baleares y repertorio para su aplicación. Edición Oficial. Madrid: Editorial Reus, 1925.

- Consejo de Economía Nacional. Estadísticas del Comercio Exterior de España. Madrid: Sucesores de Peña-Cruz and Sucesores de Ribadeneyra, 1922-1928.

- Diario de Sesiones del Congreso de Diputados. Madrid, 1931-1936.

- Dirección General de Política Arancelaria, Aranceles de aduanas para la península e islas baleares: aprobados por real decreto de 12 de febrero de 1922 y complementados con las disposiciones dictadas hasta el 2 de julio de 1934. Edición oficial. Madrid: Editorial Reus, 1934.

- Gaceta Oficial de Madrid. Madrid, various years. demás países, vigente en 31 de Enero de 1930. Madrid, 1930.

- Ministerio de Hacienda. Dirección General de Aduanas. Estadísticas del Comercio Exterior de España. Madrid: Sucesores de Peña-Cruz and Sucesores de Ribadeneyra, 1929-1935. 
Recopilación de la legislación complementaria de los aranceles de aduanas y de política comercial. Madrid, various years.

Temin, Peter. "Transmission of the Great Depression." Journal of Economic Perspectives 7, no. 1 (1993): 87-102.

Tena, Antonio. "Una reconstrucción del comercio exterior español, 1914-1935: la rectificación de las estadísticas oficiales." Revista de Historia Económica-Journal of Iberian and Latin American Economic History 1, no. 1 (1985): 77-119.

—_. "El sector exterior." In Estadísticas Históricas de España, siglo XIX-XX, edited by Albert Carreras and Xavier Tafunell, 573-644. Madrid: Fundación BBVA, 2005.

"Tariff History Lessons From the European Periphery: Protection Intensity and the Infant Industry Argument in Spain and Italy 1870-1930." Historical Social Research-Historische Sozial Forschun 35, no. 1 (2010): 340-63.

Velarde, Juan. Indalecio Prieto: ministro de Hacienda. Madrid: Ministerio de Hacienda y Administraciones Públicas, 2010.

Viñas, Angel, Julio Viñuela, Fernando Eguidazu, Carlos Fernández Pulgar, and Senen Florensa. Política comercial exterior de España (1931-1975). 2 vols. Madrid: Banco Exterior de España, 1979.

Vives, Blas. "Aspectos fundamentales de la revisión de la política arancelaria de la Dictadura. Discurso.” Revista Aduanera y Tributaria 1, no. 1 (1931): 5-27. 